\title{
Atmospheric transport and chemistry of trace gases in LMDz5B: evaluation and implications for inverse modelling
}

\author{
R. Locatelli ${ }^{1}$, P. Bousquet ${ }^{1}$, F. Hourdin ${ }^{2}$, M. Saunois ${ }^{1}$, A. Cozic $^{1}$, F. Couvreux ${ }^{3}$, J.-Y. Grandpeix ${ }^{2}$, M.-P. Lefebvre Gr, $^{2,3}$, \\ C. Rio $^{2}$, P. Bergamaschi ${ }^{4}$, S. D. Chambers ${ }^{5}$, U. Karstens ${ }^{6}$, V. Kazan ${ }^{1}$, S. van der Laan ${ }^{*}$, H. A. J. Meijer ${ }^{7}$, J. Moncrieff ${ }^{8}$, \\ M. Ramonet ${ }^{1}$, H. A. Scheeren ${ }^{4,8}$, C. Schlosser ${ }^{9}$, M. Schmidt ${ }^{1, * *}$, A. Vermeulen ${ }^{10}$, and A. G. Williams ${ }^{5}$ \\ ${ }^{1}$ Laboratoire des Sciences du Climat et de l'Environnement (LSCE), Gif-sur-Yvette, France \\ ${ }^{2}$ Laboratoire de Meteorologie Dynamique (LMD) - Jussieu, Paris, France \\ ${ }^{3}$ Centre National de Recherches Météorologiques (CNRM-Game), Météo-France, Toulouse, France \\ ${ }^{4}$ Institute for Environmental and Sustainability, Joint Research Centre, European Commission, Ispra, Italy \\ ${ }^{5}$ Australian Nuclear Science and Technology Organisation, Locked Bag 2001, Kirrawee DC, NSW 2232, Australia \\ ${ }^{6}$ Max Planck Institute for Biogeochemistry, Jena, Germany \\ ${ }^{7}$ Centre for Isotope Research, ESRIG, University of Groningen, Nijenborgh 4, 9747 AG Groningen, the Netherlands \\ ${ }^{8}$ School of GeoSciences and Centre for Terrestrial Carbon Dynamics, University of Edinburgh, UK \\ ${ }^{9}$ Federal Office for Radiation Protection (BfS), Willy-Brandt-Str. 5, 38226 Salzgitter, Germany \\ ${ }^{10}$ Energy research Centre of the Netherlands (ECN), Petten, the Netherlands \\ * now at: Centre for Ocean and Atmospheric Sciences, School of Environmental Sciences, University of East Anglia, UK \\ *** now at: Institut für Umweltphysik, Heidelberg University, INF 229, 69120 Heidelberg, Germany
}

Correspondence to: R. Locatelli (robin.locatelli@lsce.ipsl.fr)

Received: 4 June 2014 - Published in Geosci. Model Dev. Discuss.: 31 July 2014

Revised: 10 December 2014 - Accepted: 16 December 2014 - Published: 3 February 2015

\begin{abstract}
Representation of atmospheric transport is a major source of error in the estimation of greenhouse gas sources and sinks by inverse modelling. Here we assess the impact on trace gas mole fractions of the new physical parameterizations recently implemented in the atmospheric global climate model LMDz to improve vertical diffusion, mesoscale mixing by thermal plumes in the planetary boundary layer (PBL), and deep convection in the troposphere. At the same time, the horizontal and vertical resolution of the model used in the inverse system has been increased. The aim of this paper is to evaluate the impact of these developments on the representation of trace gas transport and chemistry, and to anticipate the implications for inversions of greenhouse gas emissions using such an updated model.

Comparison of a one-dimensional version of LMDz with large eddy simulations shows that the thermal scheme simulates shallow convective tracer transport in the PBL over land very efficiently, and much better than previous versions of the model. This result is confirmed in three-dimensional simulations, by a much improved reproduction of the radon-222 di-
\end{abstract}

urnal cycle. However, the enhanced dynamics of tracer concentrations induces a stronger sensitivity of the new LMDz configuration to external meteorological forcings. At larger scales, the inter-hemispheric exchange is slightly slower when using the new version of the model, bringing them closer to observations. The increase in the vertical resolution (from 19 to 39 layers) significantly improves the representation of stratosphere/troposphere exchange. Furthermore, changes in atmospheric thermodynamic variables, such as temperature, due to changes in the PBL mixing modify chemical reaction rates, which perturb chemical equilibriums of reactive trace gases.

One implication of LMDz model developments for future inversions of greenhouse gas emissions is the ability of the updated system to assimilate a larger amount of highfrequency data sampled at high-variability stations. Others implications are discussed at the end of the paper. 


\section{Introduction}

A better knowledge of biogeochemical cycles is fundamental to improving our understanding of processes and feedbacks involved in climate change. Carbon dioxide $\left(\mathrm{CO}_{2}\right)$ and methane $\left(\mathrm{CH}_{4}\right)$, the two main anthropogenic greenhouse gases, currently play a key role in biogeochemical cycles. Improving the global estimates of their sources and sinks are therefore highly sought after. To date, considerable uncertainty remains regarding the annual global terrestrial $\mathrm{CO}_{2}$ sink (Ciais et al., 2013), and a consensus has yet to be reached on the cause of recent increases of atmospheric methane (Rigby et al., 2008; Bousquet et al., 2011; Kai et al., 2011; Aydin et al., 2011; Levin et al., 2012). Indeed, large uncertainties still exist in the estimates of major methane sources and sinks (Kirschke et al., 2013; Ciais et al., 2013).

One of the methods to derive greenhouse gas sources and sinks is to adapt the inverse problem theory to the atmospheric sciences: from observations (in situ measurements, satellite retrievals, etc.) and a prior knowledge of emissions, it is possible to derive emissions of a given greenhouse gas using a Bayesian formalism together with an atmospheric chemistry-transport model (CTM), or with a global climate model (GCM) (Rodgers, 2000; Tarantola, 2005). This method has been widely used since the mid-1990s to estimate sources and sinks of $\mathrm{CO}_{2}$ (Rayner et al., 1999; Bousquet et al., 1999; Peylin et al., 2005; Chevallier et al., 2005) and $\mathrm{CH}_{4}$ (Hein et al., 1997; Houweling et al., 1999; Bousquet et al., 2006; Chen and Prinn, 2006; Bergamaschi et al., 2010, 2013; Houweling et al., 2014).

The consistency of inverse estimates of regional emissions by inverse modelling is mostly dependent on: (a) the number, accuracy and spatio-temporal coverage of observations constraining the inversion, (b) the ability of the CTM to simulate atmospheric processes (Gurney et al., 2002; Locatelli et al., 2013), and (c) the quality of prior estimates. Regarding observations, the situation is slowly improving but remains at the same time problematic: more atmospheric data has become available in recent years (continuous surface measurements, aircraft profiles, remote sensing from the surface or from space) but their temporal sustainability is not yet guaranteed (Houweling et al., 2012). On the modelling side, developments have been made to improve resolution and transport, but the assimilation of continental sites close to emission areas remains challenging for global CTMs with too coarse resolutions. For example, Geels et al. (2007) showed large differences in the ability of CTMs to reproduce synoptic variations of $\mathrm{CO}_{2}$ at continental sites. More recently, Locatelli et al. (2013) showed that deficiencies in CTM simulations of atmospheric methane are responsible for errors in inverse estimates increasing from $5 \%$ at the global scale to $150 \%$ at model resolution $(\sim 300 \mathrm{~km} \times 300 \mathrm{~km})$. These two studies and others (Chevallier et al., 2010; Houweling et al., 2010; Kirschke et al., 2013) have pointed out that the skills of CTMs require urgent improvements to reduce uncertain- ties in trace gas source/sink estimates and take full advantage of the available and increasing data.

In the PYVAR (Python variational) variational inverse framework (Chevallier et al., 2005), the transport component (an offline version of the LMDz atmospheric model; Hourdin et al., 2006) is coupled to a simplified linear chemical scheme, SACS (Simplified atmospheric chemistry system; Pison et al., 2009) and simulates atmospheric gas concentrations from prior emission estimates. Recently, some limitations of the PYVAR-LMDz-SACS combination regarding large-scale transport have been highlighted, which may lead to biases in estimates of trace gas emissions. For example, Locatelli et al. (2013) showed that the fast inter-hemispheric (IH) exchange rate of LMDz-SACS introduces a negative (positive) bias in estimated $\mathrm{CH}_{4}$ emissions in the Southern (Northern) Hemisphere compared to CTMs with slower IH exchange rates. Moreover, as with some other coarseresolution CTMs, LMDz-SACS appears to underestimate synoptic variability of trace gases at the surface compared to observations (Geels et al., 2007; Locatelli et al., 2013). Consequently, biases can occur in emission estimates, especially at the regional scale. The versions of LMDz-SACS used so far are also in the low resolution range of CTMs used worldwide to simulate greenhouse gas distribution (Patra et al., 2011), in both the vertical (19 layers representing the surface from surface to $2 \mathrm{hPa})$ and horizontal $\left(3.75^{\circ} 23^{\prime} \times 2.5^{\circ} 23^{\prime}\right)$ dimensions. Overall, several aspects of LMDz need to be updated to address these trace gas modelling issues.

Paths to improve the representation of trace gas concentrations may differ for "online" (GCM) and "offline" (CTM) models. "Offline" models use external meteorological fields (from weather forecast centres) for inputs inducing a dependence on meteorological model performances. Consequently, intensive and consistent pre-processing of the meteorological fields is necessary to ensure the quality and comparability of results. Indeed, Bregman et al. (2001) showed that performance of CTMs might largely differ depending on how meteorological fields are used. For example, Segers et al. (2002) designed an interpolation and re-gridding method for mass fluxes in the spectral domain (as is generally employed in meteorological models). Furthermore, to limit inconsistencies, the meteorological model and CTM should employ similar physical parameterizations. Thus, physical parameterizations are generally imposed by weather forecast centre strategies; although some adaptations may be made. For example, Monteil et al. (2013) proposed an extension of their advection scheme by accounting for horizontal mixing in the presence of deep convection in order to improve the modelling of IH exchange, which is underestimated by the TM5 model, as shown in Patra et al. (2011).

"Online" models compute their own transport and meteorology, using physical conservation laws, and parameterize sub-grid scale transport processes at the same time. Physical, dynamical and chemical processes interact directly and consistently as they do in the real world. Consequently, efforts 
to improve the atmospheric transport of "online" models are generally focused on the physical and/or dynamical schemes. The efficacy of these developments can then be evaluated using trace gas observations (Belikov et al., 2013; Geels et al., 2007). A caveat of online models representing trace gas concentrations is that they need to be nudged towards real meteorology in some way if one wants to represent the actual transport for a given year.

A new version of the LMDz physics was recently developed and implemented (Hourdin et al., 2013b; Rio and Hourdin, 2008) to simulate processes in the troposphere more realistically, especially in the planetary boundary layer (PBL; turbulent transport, mixing by coherent structures of the convective boundary layer, convection). The vertical resolution of the model version for the inverse system has also been doubled (from 19 to 39 layers) and the horizontal resolution improved (from 72 to 96 points in latitude). The impact of these modifications has already been evaluated in a dynamical and physical sense (Hourdin et al., 2006, 2013b) but not yet for the transport of trace gases.

The aim of this paper is to evaluate the ability of the modified LMDz model to transport trace gases, with the ultimate goal to use this new version to estimate trace gas sources and sinks with inverse modelling. In Sect. 2, we describe the various LMDz configurations compared and evaluated in this study. In Sect. 3.1, we compare a single column model version of LMDz to a large eddy simulation (LES) in order to evaluate the new PBL transport parameterizations. In Sect. 3.2, we use radon-222 observations to evaluate the ability of the new parameterizations to reproduce diurnal cycles of trace gas concentrations. In Sect. 4, we evaluate the large scale model behaviour. Finally, in Sect. 5, we discuss the implications of this new version of the LMDz model for future inversion studies of greenhouse gas emissions.

\section{Modelling of atmospheric transport in LMDz}

The LMDz GCM is the atmospheric component of the Institut Pierre-Simon Laplace Coupled Model (IPSL-CM) used for climate change projections in the 3rd (Marti et al., 2010) and 5th (Dufresne et al., 2013) phase of the Coupled Model Intercomparison Project (CMIP3 and CMIP5, respectively), which contributed significantly to the two most recent Intergovernmental Panel on Climate Change (IPCC) assessment reports.

The LMDz version used in the inverse system of Chevallier et al. (2005) parameterizes deep convection according to Tiedtke (1989). The vertical diffusion scheme of Louis (1979) operates in the boundary layer, in which turbulent diffusion coefficients depend on a Richardson number computed from local atmospheric gradients. Recent parameterizations have been integrated into LMDz in order to better represent some important sub-grid scale processes. Indeed, sub-grid scale schemes using a local approach (as in Louis,
1979) are not able to simulate the different scales acting in the boundary layer (Zhang et al., 2005). In particular, coherent structures of the convective boundary layer such as thermals are not represented well by such local approaches (Bougeault and Lacarrère, 1989; Rio and Hourdin, 2008).

With these issues in mind, Hourdin et al. (2002) developed a mass-flux approach to describe the dry convective structures of the boundary layer: the thermal plume model. This model has been combined with the Yamada (1983) diffusion scheme to represent local and non-local transport within the convective boundary layer in a unified way. The thermal plume model has been extended to represent both dry and cloudy thermals by Rio and Hourdin (2008). The result is a significant improvement of the representation of the diurnal cycle of thermodynamical and dynamical variables of the boundary layer and of shallow cumulus clouds.

Concerning the parameterization of deep convection, the Tiedtke (1989) scheme has been replaced by that of Emanuel (1991). Both are so-called mass-flux schemes. The atmospheric column is divided into three parts: a convectivescale updraft, a convective-scale downdraft, and compensating subsidence in the environment. Both convective-scale updraft and downdraft are handled differently in the two schemes. The Tiedtke scheme uses for the updraft an entraining plume approach with prescribed entrainment and detrainment rates at each level. The downdraft is driven by evaporation in a way to maintain it saturated until cloud base. The Emanuel scheme uses for the updraft the so-called "episodic mixing and buoyancy sorting" approach, in which parcels of the adiabatic updraft originating from low-level layers are mixed with environmental air at each level, forming mixtures of different buoyancies. Each mixture then moves adiabatically up or down to its level of neutral buoyancy where it detrains into the environment. A fixed part of precipitation falls outside the clouds at each level, where it evaporates, driving an unsaturated downdraft driven by buoyancy. Hourdin et al. (2006) demonstrated that the Emanuel (1991) scheme improved the representation of the Hadley-Walker circulation in LMDz. Heinrich and Jamelot (2011), who studied the transport of the natural radionuclides ${ }^{210} \mathrm{~Pb}$ and ${ }^{7}$ Be using Tiedtke (1989) and Emanuel (1991) schemes for convection and different scavenging parameterizations, confirmed that Emanuel (1991) captures the mean climate better, even though none of the configurations lead to satisfactory agreements on a daily scale in the Tropics. Rio et al. (2009) showed that the thermal plume model, by representing the shallow convection phase, delays the initiation of deep convection. The coupling of the Emanuel (1991) scheme with the parameterization of cold pools developed by Grandpeix and Lafore (2010) via a new triggering and closure formulation also leads to the self-sustainment of deep convection through the afternoon and early evening, in better agreement with observations.

Concerning model resolution in the inverse system, the current version of LMDz has a grid of 96 cells in longitude by 
Table 1. Description of the sub-grid scale schemes used in the three configurations of LMDz (TD, SP and NP).

\begin{tabular}{llll}
\hline $\begin{array}{l}\text { LMDz } \\
\text { configuration }\end{array}$ & $\begin{array}{l}\text { Boundary layer } \\
\text { mixing }\end{array}$ & Deep convection & $\begin{array}{l}\text { Reference } \\
\text { version }\end{array}$ \\
\hline TD & $\begin{array}{l}\text { Vertical diffusion (Louis, 1979) } \\
\text { Vertical diffusion (Louis, 1979) } \\
\text { + adjustments (Deardorff, 1966) }\end{array}$ & Tiedtke (1989) & LMDz3 \\
& $\begin{array}{l}\text { Vertical diffusion (Yamada, 1983) } \\
+ \text { Thermal plume model (Rio and Hourdin, }\end{array}$ & $\begin{array}{l}\text { Emanuel (1991) } \\
\text { modified by Grandpeix } \\
\text { and Lafore (2010) }\end{array}$ & LMDz5B \\
& 2008; Rio et al., 2009) & LMD & \\
\hline
\end{tabular}

72 cells in latitude (about $3.75^{\circ} 23^{\prime} \times 2.5^{\circ} 23^{\prime}$ ), with 19 layers in the vertical. This configuration was adopted in 2003 to balance computing time issues regarding variational inversions and spatio-temporal resolution of flux estimates by inverse methods. With recent advances in computing power, the coarse LMDz-SACS resolution, especially in the vertical, is thought to have become a significant limitation. Consequently, a new LMDz-SACS configuration was designed with 39 vertical layers, and 96 points both in longitudinal and latitudinal directions.

We henceforth use "NP" to refer to the new physical parameterization package of LMDz: the Yamada (1983) diffusion scheme combined with the cloudy thermal plume model (Rio and Hourdin, 2008; Rio et al., 2009) and the Emanuel (1991) convection scheme revisited by Grandpeix and Lafore (2010) with a new triggering and closure formulation and the representation of cold pools driven by the evaporation of precipitation. This configuration is very similar to LMDz5B (Hourdin et al., 2013b), which has been used to produce a set of CMIP5 simulations with IPSL-CM5B. We use "TD" to refer to the LMDz configuration using the combination of the Tiedtke (1989) and Louis (1979) schemes. In the literature, this version is known as LMDz3 ( $\mathrm{Li}, 1999$; $\mathrm{Li}$ and Conil, 2003). Finally, we also evaluate an intermediate version of LMDz (hereafter named "SP" standing for Standard Physic), which uses the Emanuel (1991) scheme for convection, but not the thermals, and also differs from TD in the boundary layer mixing (a counter-gradient term on potential temperature is added according to Deardorff, 1966). This last configuration is the LMDz5A version used for CMIP5 simulations with IPSL-CM5A and is very close to the original LMDz4 version (Hourdin et al., 2006). Unless otherwise specified, all versions of LMDz are run with 96 points in both horizontal directions, and with 39 vertical layers. Moreover, horizontal winds in all versions are nudged towards ERA-Interim reanalysed horizontal winds. A summary of model versions is presented in Table 1.

\section{Evaluation of atmospheric transport in the PBL}

In this section, we investigate the ability of the LMDz model to represent transport of tracers in the planetary boundary layer, first in one dimension (Sect. 3.1) and then with the three-dimensional version of the model (Sect. 3.2).

\subsection{LMDz single column model vs. large eddy simulation}

In recent decades, several comparisons have been made between single column models (SCM) and large eddy simulations (LES) to better understand physical parameterizations (Ayotte et al., 1996; Galmarini, 1998).

Here we compare three single-column versions of LMDz with LES from the non-hydrostatic model Meso-NH (Lafore et al., 1998). Originally, these LES were designed to evaluate the conditional sampling used by Couvreux et al. (2010) for the improvement of convective boundary layer mass-flux parameterizations. Here, we use them to characterize the atmospheric transport of surface-emitted short lived tracers, and evaluate corresponding simulations by three SCM versions of LMDz. The case chosen for evaluation represents a situation of shallow continental convection in the Southern Great Plains (SGP) of the Atmospheric Radiation Measurement (ARM) site on 21 June 1997. More details about this case can be found in Brown et al. (2002). The tracer is emitted every minute with a constant surface flux, and has a firstorder decay time constant of $15 \mathrm{~min}$. The horizontal LES resolution is $100 \mathrm{~m}$ and there are 100 vertical levels between the surface and $4000 \mathrm{~m}$ with a regular $40 \mathrm{~m}$ spacing. Given that, circulations related to main coherent structures of PBL, characterized by updraft and downdraft motions, are explicitly represented in the LES. On the contrary, these circulations are parameterized in climate models. Thus, we consider the LES as our point of reference.

The three versions of LMDz-SCM used are differentiated by their deep convection and vertical diffusion parameterizations. Firstly, SCM-TD uses the Tiedtke (1989) deep convection scheme, while SCM-SP uses the Emanuel (1991) deep convection scheme. Both of these versions use a local formulation of the turbulence to represent small-scale mixing. Secondly, SCM-NP contains the most recent physical parameterizations introduced in $\mathrm{LMDz}$ (thermal plume model of Rio and Hourdin, 2008; Rio et al., 2009 combined with Yamada, 1983 vertical diffusion). In SCM-TD and SCM-SP, the deep convection scheme is meant to represent both shallow and 

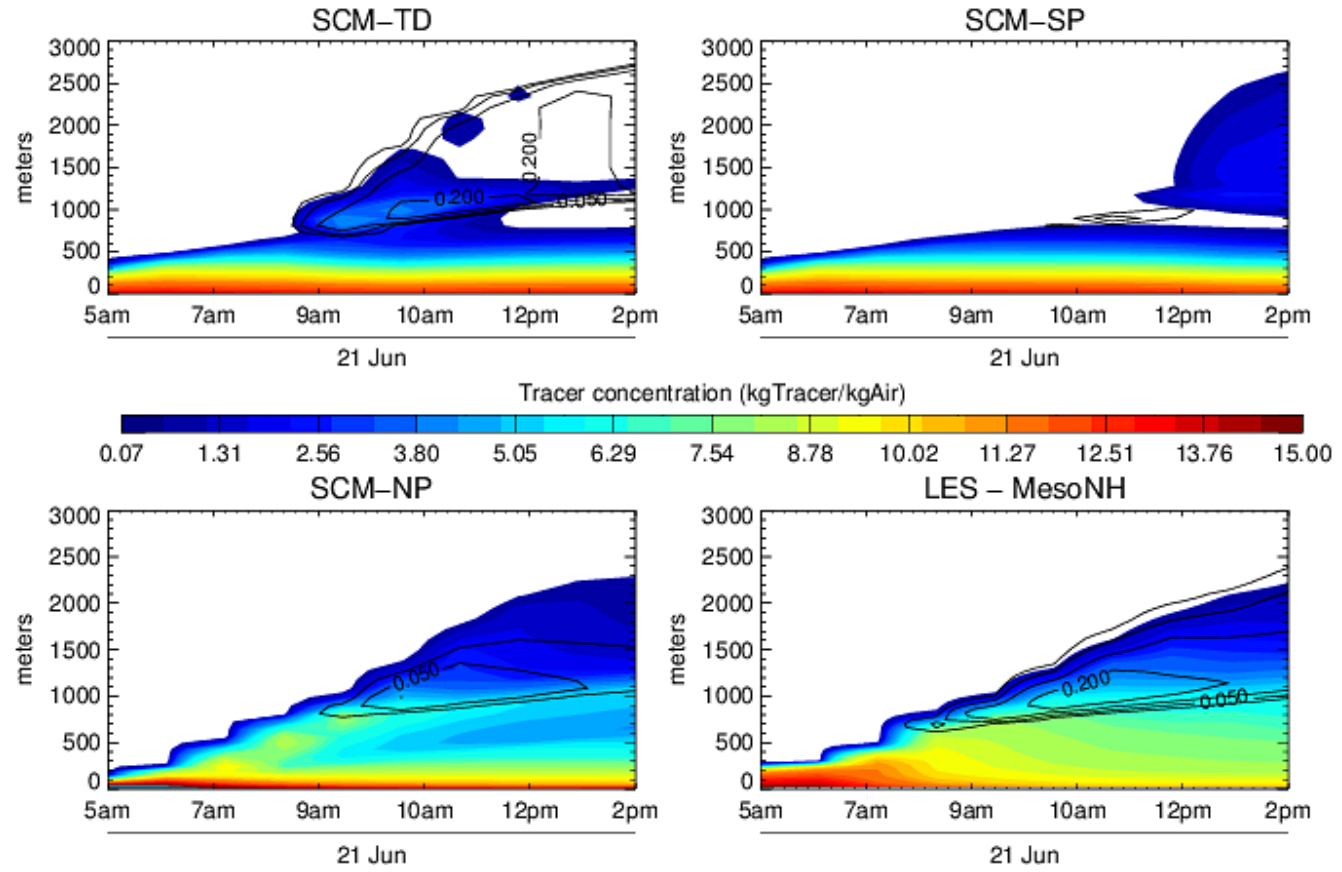

Figure 1. Atmospheric transport of an ideal tracer simulated by three different versions of a single-column configuration of LMDz model (SCM-TD (top left), SCM-SP (top right) and SCM-NP (bottom left)). These one-dimensional simulations are compared with a Large Eddy Simulation simulation (bottom right) of Meso-NH. The tracer is emitted at the surface and has a half-time life of 15 min in the atmosphere. This case represents an ideal shallow convection over land case at the Southern Great Plains of the Atmospheric Radiation Measurement site on 21 June 1997. Black contours represent the total cloud cover (in fraction of the grid cell). Contour values are $0.025,0.05,0.1$ and $0.2 \%$.

deep convection so that the Tiedtke and Emanuel schemes have to be activated to represent this case of fair-weather cumulus. However, in SCM-NP, shallow convection is handled by the thermal plume model and the Emanuel scheme is deactivated in this simulation.

During the $9 \mathrm{~h} \mathrm{LES} \mathrm{(Fig.} \mathrm{1,} \mathrm{bottom} \mathrm{right),} \mathrm{the} \mathrm{usual} \mathrm{bound-}$ ary layer thickening is observed during the morning related to incoming solar radiation. Physical processes acting in the boundary layer (small-scale turbulence, convection, mixing by thermal plumes, etc.) vertically distribute the surfaceemitted tracer. At 1 p.m. (Local Time), the tracer is diluted within a layer reaching $2000 \mathrm{~m}$.

The three LMDz-SCM versions exhibit markedly different skills in their attempt to reproduce the LES reference case. In the SCM-TD and SCM-SP simulations, the tracer is confined within a $500 \mathrm{~m}$ layer near the surface until 9 a.m. (SCM-TD) or 12 p.m. (SCM-SP). In SCM-TD, some tracer mass is transported vertically after 9 p.m., but tracer concentrations in the upper layers stay much lower than in the LES case. Indeed, tracer mixing ratios are insignificant at $2000 \mathrm{~m}$ after 11 a.m., while they reach $3.5 \mathrm{~kg} \mathrm{~kg}^{-1}$ in the LES. In SCM-SP, upper mixing ratios are more consistent after 12 p.m. but the vertical gradient from the surface to $2000 \mathrm{~m}$ is badly represented compared to the LES. In particular, surface mixing ratios are largely over-estimated $\left(9 \mathrm{~kg} \mathrm{~kg}^{-1}\right.$ in the LES versus $13 \mathrm{~kg} \mathrm{~kg}^{-1}$ in SCM-SP). These statements suggest that vertical mixing during a shallow convection case are badly represented in SCM-TD and SCM-SP. By contrast, SCM-NP shows better agreement with the LES reference: the tracer is vertically mixed in a layer that is thickening during the day as in the reference. Given that the Emanuel (1991) scheme was deactivated in the SCM-NP simulations, in order to highlight thermal actions on vertical mixing, it appears that thermals and vertical diffusion are responsible for the good representation of atmospheric transport in this case of shallow convection. However, it is also important to note that tracer mixing ratios are slightly under-estimated in the mixed layer. It is especially true at $12 \mathrm{p} . \mathrm{m}$. around $500 \mathrm{~m}$ : SCM-NP simulates tracer mixing ratios of $5 \mathrm{~kg} \mathrm{~kg}^{-1}$, while they reach $8 \mathrm{~kg} \mathrm{~kg}^{-1}$ in the LES. The underestimation of tracer concentrations in the mixed layer could be due to an underestimation of detrainment from thermals at those levels or to the underestimation of vertical mixing by the diffusive scheme.

Moreover, we notice that the cloud fraction (black contours) is underestimated in SCM-NP. Indeed, SCM-NP simulates a cloud fraction of $5 \%$ compared to $20 \%$ in the LES. It is known that cumulus cause a venting of the boundarylayer air as shown in Williams et al. (2010). Consequently, the underestimation of the cloud fraction simulated by SCMNP could induce an underestimation of the vertical transport of gas. However, here, the cloud fraction is not directly given by the thermal plume model but is computed from a cloud 


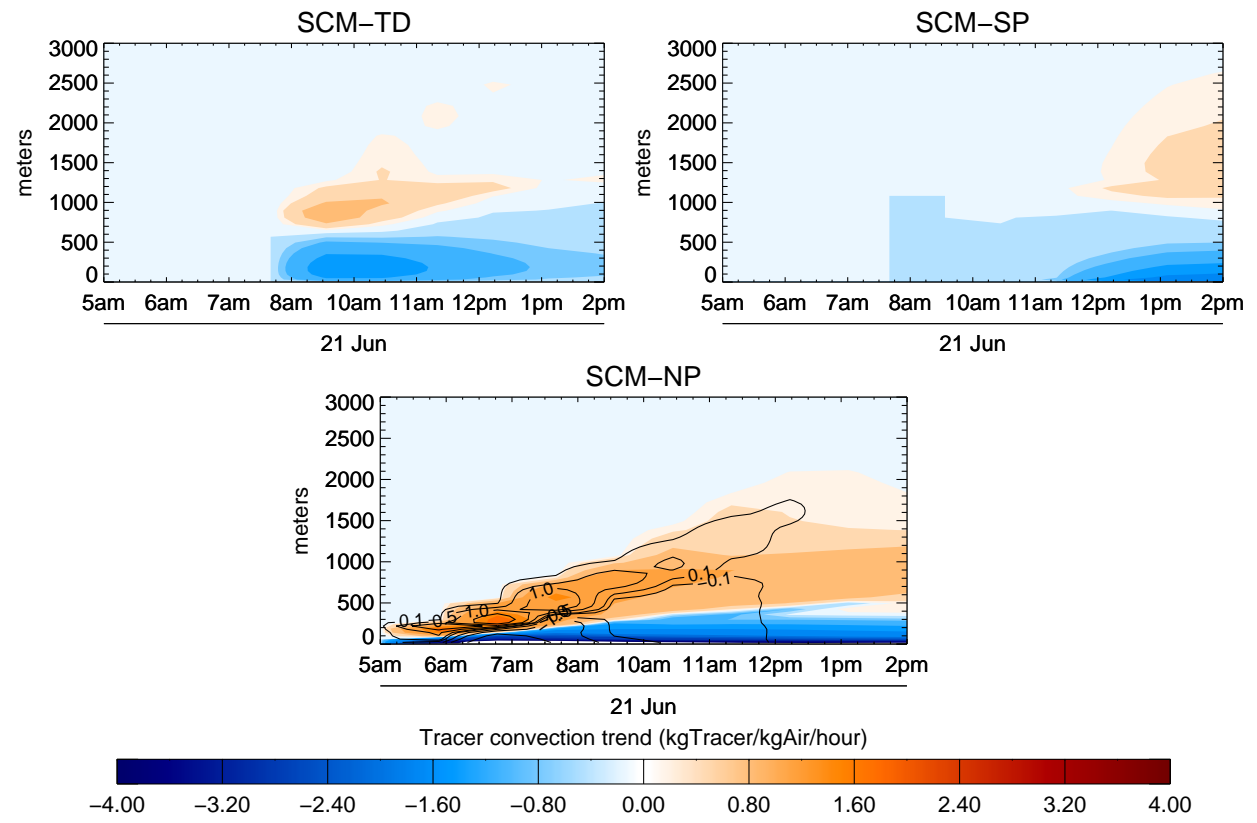

Figure 2. Deep convection trends (in kgTracer/kgAir/hour) simulated in SCM-TD (top left) and SCM-SP (top right) configurations are compared with thermal trends simulated by SCM-NP in an ideal shallow convection over land case. Positive (Negative) trends are represented in shades of red (blue, respectively). Black contours represent tracer trends in the LES. Contour values are $2.0,1.0,0.5$ and $0.1 \mathrm{~kg} \mathrm{~kg}^{-1} \mathrm{~h}^{-1}$ (and for negative trends, same values with a negative sign).

scheme that diagnoses cloud cover from thermal properties. Thus, the underestimation of the cloud cover is not necessarily associated with an underestimation of the vertical transport by thermal plumes, because it can be due to limitations of the cloud scheme or to an overestimation of the cloud condensate that is converted into precipitation.

We hereafter define trends as the change of mixing ratios (or activity for ${ }^{222} \mathrm{Rn}$, Sect. 3.2.2) due to a certain transport process (unit: mass mixing ratio (or $\mathrm{Bq} \mathrm{m}^{-3}$ for ${ }^{222} \mathrm{Rn}$ ) per a unit of time; processes: PBL mixing, convection, thermals and advection). Here, the unit is kilogram per kilogram per hour $\left(\mathrm{kg} \mathrm{kg}^{-1} \mathrm{~h}^{-1}\right)$. Trends in the vertical transport of tracers in the boundary layer due to deep convection (SCM-TD and SCM-SP) and thermal plumes (SCMNP) are shown in Fig. 2. Positive trends (red colours) at a specific level mean that the process brings tracer to this level. Conversely, negative trends (blue colours) mean that the process moves some tracer to another level. In SCMTD and SCM-SP, vertical transport of the tracer within the PBL (after 09:00 and 24:00 LT respectively) is mainly due to deep convection processes (Fig. 2, top left and top right). In SCM-NP, on the other hand, the thermal plume model is very efficient for transporting tracers from the surface to the top of the boundary layer during daylight hours (Fig. 2, bottom). Moreover, trends in tracer mixing ratio simulated by the LES is represented on Fig. 2 (bottom) by black contours. It appears that trends due to thermals are strongly in agreement with trends in tracer mixing ratio simulated by the LES. This confirms that the vertical transport of tracer is well simulated in this specific case due to thermal processes. On the contrary, it appears that convection schemes like Tiedtke (1989) or Emanuel (1991) are not able to properly simulate shallow convection over land in this case. Indeed, they are not really designed to simulate convection reaching only $2000 \mathrm{~m}$ height, whereas the modelling of atmospheric transport within cumulus-topped convective boundary layer is well reproduced by the thermal scheme (Rio and Hourdin, 2008). This case of the atmospheric transport of a short-lived tracer confirms that the thermal plume model of Rio and Hourdin (2008) and Rio et al. (2009) is really efficient in properly simulating shallow convective mixing over land, where the PBL is topped by cumulus clouds. Similar results have been presented in Hourdin et al. (2002) for the representation of the vertical structure of the scalar transport for various clear boundary layer cases.

\subsection{Three-dimensional simulations of ${ }^{222} \mathrm{Rn}$}

\subsubsection{Statistical evaluation in the PBL}

After a promising one-dimensional evaluation (Sect. 3.1), we seek here to evaluate the new physical parameterizations of LMDz for three-dimensional simulations on longer time and spatial scales. To do so, we used the different versions of LMDz (Table 1) to simulate concentrations of the natural radioactive gas radon $\left({ }^{222} \mathrm{Rn}\right)$. Radon is particularly well suited to evaluating diurnal mixing in the continental lower tropo- 
Table 2. Description of the different surface stations used for the evaluation of 3-D simulations of ${ }^{222} \mathrm{Rn}$.

\begin{tabular}{llll}
\hline Station ID & Name & Country & Reference \\
\hline AMS & Amsterdam Island & France & Gaudry et al. (1990) \\
CB1 $^{2}$ & Cabauw (20 m) & Netherlands & Popa et al. (2011), Vermeulen et al. (2011) \\
CB$^{2}$ & Cabauw (200 $\left.{ }^{2}\right)$ & Netherlands & Popa et al. (2011), Vermeulen et al. (2011) \\
CGO $^{2}$ & Cape Grim & Australia & Griffiths et al. (2010) \\
CPT $^{2}$ & Cape Point & South Africa & Slemr et al. (2013) \\
EGH $^{1}$ & Egham & United Kingdom & Lowry et al. (2001) \\
GIF $^{1}$ & Gif-sur-Yvette & France & Lopez et al. (2012), Yver et al. (2009) \\
GSN $^{2}$ & Gosan & South Korea & Kim et al. (2014) \\
HEI $^{1}$ & Heidelberg & Germany & Levin et al. (2002) \\
IPR $^{2}$ & Ispra & Italy & Scheeren and Bergamaschi (2012) \\
LUH $^{2}$ & Lucas Heights & Australia & A. Williams (personal communication, 2014) \\
LUT $^{2}$ & Lutjewad & Netherlands & van der Laan et al. (2010) \\
MHD $^{1}$ & Mace Head & Ireland & Biraud et al. (2000) \\
MLO $^{2}$ & Mauna Loa & Hawaii, USA & Chambers et al. (2013) \\
PAL $^{1}$ & Pallas & Finland & Hatakka et al. (2013) \\
RIC $^{2}$ & Richmond & Australia & A. Williams (personal communication, 2014) \\
SIL $^{1}$ & Schauinsland & Germany & Xia et al. (2010) \\
TTA $^{2}$ & Angus & United Kingdom & Smallman et al. (2014) \\
\hline
\end{tabular}

sphere because it is a poorly soluble gas, and it is only emitted by continental surfaces and has a half-life of 3.8 days. These physical characteristics have lead radon to be used in many studies evaluating the performance of GCMs (Mahowald et al., 1997; Genthon and Armengaud, 1995; Belikov et al., 2013). Radon is produced from the radioactive decay of uranium-238 and is emitted fairly uniformly from terrestrial surfaces. Generally, radon emissions are quite well known globally (Zhang et al., 2011), and it is considered that a flux of 1 atom $\mathrm{cm}^{-2} \mathrm{~s}^{-1}$ is approximately valid for ice-free terrestrial surfaces (Jacob et al., 1997). While continuous radon measurements exist worldwide, the coverage is better in Europe. Therefore, here we use a refined radon flux map for European emissions (Karstens et al., 2014), the rest of the continental lands emitting 1 atom $\mathrm{cm}^{-2} \mathrm{~s}^{-1}$ between $60^{\circ} 23^{\prime} \mathrm{S}$ and $60^{\circ} 23^{\prime} \mathrm{N}$ and 0.5 atom $\mathrm{cm}^{-2} \mathrm{~s}^{-1}$ between $60^{\circ} 23^{\prime}$ and $70^{\circ} 23^{\prime} \mathrm{N}$ (excluding Greenland). Elsewhere, no radon flux is considered. As a consequence, our analysis is focused mainly on European stations (11 stations in Western Europe), even though results for stations outside Europe are also presented. Table 2 describes the different stations where ${ }^{222} \mathrm{Rn}$ measurements are available for this study. Note that different measurement techniques are used at the stations to measure ${ }^{222} \mathrm{Rn}$. In particular, ${ }^{222} \mathrm{Rn}$ measurements using methods based on short-lived daughters applied a station dependent disequilibrium factor (Schmithüsen, 2015).

Figure 3 provides a statistical overview of the performance of the NP and TD models by comparing measured and simulated hourly radon concentrations over a 6-year period (2006-2011). Here the red boxplots represent the NP simulations, whereas the green boxplots correspond to simulations using the current version of LMDz in PYVAR (the TD simulation). The black boxplots represent the observations.

For most stations, the box width (representing the interquartile range) is relatively similar between observed and simulated values. However, large differences occur in the extreme values (black circles). The observed high concentration "outliers" correspond primarily to pre-dawn measurements on stable nights when PBL heights are lowest. A considerably better agreement is generally found between observed outliers and those simulated by NP, meaning that the NP simulation is better at representing mixing during the night associated with stable atmospheric conditions. On the other hand, nocturnal mixing in TD results in considerable underestimation of the outlier radon values.

More precisely, skills of TD and NP simulations may be very different at some specific stations. For example, NP simulation gives remarkably good results at Heidelberg (HEI) station where NP is able to reproduce the strong diurnal cycle of ${ }^{222} \mathrm{Rn}$ concentrations measured at this site. On the contrary, TD time series at Heidelberg are very smooth and the diurnal cycle amplitude is strongly under-estimated. Similar results are found at Richmond (RIC) station in Australia. At Ispra (IPR) station, both TD and NP models disagree with the observations, although NP boxplot is closer to the observation boxplot than TD. Indeed, $\mathrm{LMDz}$ is not able to properly simulate radon concentrations at this station, which is bordered by the Po Valley region in the south and the Alps Mountains in the north. One possible reason of this failure is the relatively coarse horizontal resolution of LMDz, for this complex location. This is a typical example of representativity errors in global models. 


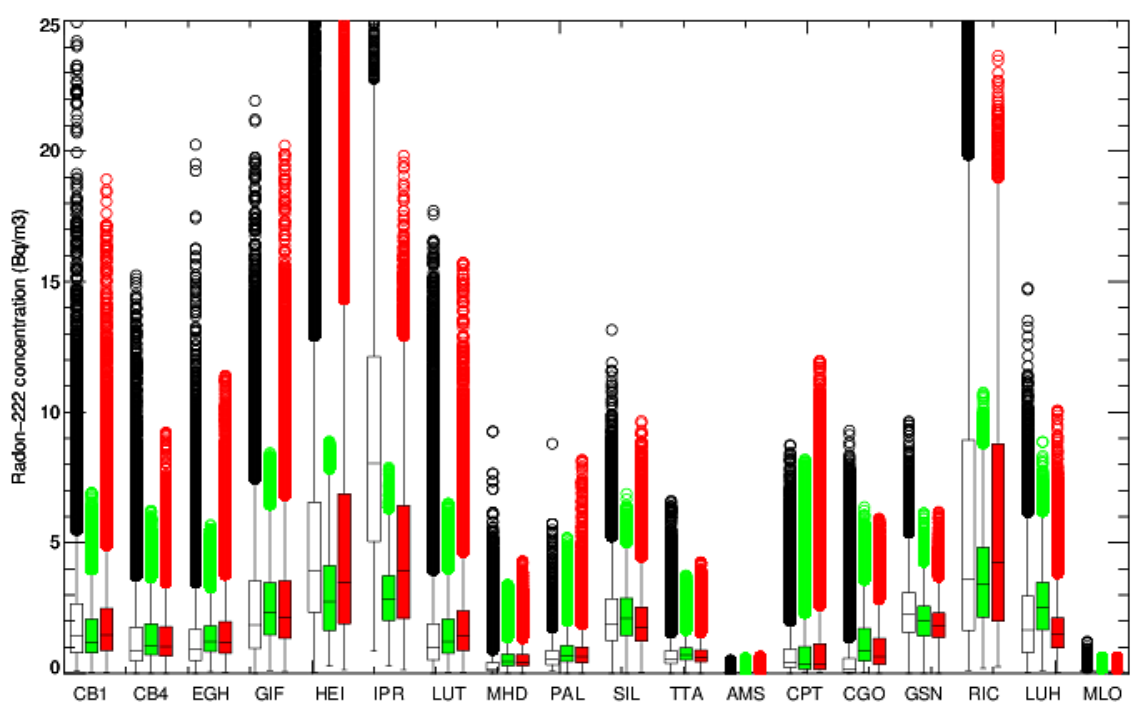

Figure 3. Comparisons of ${ }^{222} \mathrm{Rn}$ boxplot simulated by NP (red) and TD (green) versions of LMDz with boxplot based on measurements (black) sampled at 18 surface stations over a 6-year period (2006-2011). The bottom and the top of the box are the first and the third quartiles of the data distribution. The band inside the box is the median. The ends of the whiskers represent the lowest datum still within 1.5 $\cdot$ IQR (inter-quartile range) of the lower quartile and the highest datum still within $1.5 \cdot$ IQR of the upper quartile. Stations are marked by three-letter abbreviations (see Table 2).

\subsubsection{Case studies in the PBL}

Here, we illustrate some typical LMDz behaviours in two case studies: at Heidelberg (Germany) in April 2009 (Figs. 4 and 5) and Lutjewad (Netherlands) in February 2008 (Figs. 6 and 7).

At Heidelberg in April 2009 (Fig. 4), NP reproduces the radon diurnal cycle very well, especially peak nocturnal concentrations between the 8 and 16 April. TD, on the other hand, poorly reproduces the amplitude of the diurnal cycle; with peak nocturnal values $\left(7 \mathrm{~Bq} \mathrm{~m}^{-3}\right)$ reaching less than half of the observed peaks $\left(18 \mathrm{~Bq} \mathrm{~m}^{-3}\right)$. As a consequence, for the whole month of April, normalized standard deviations (NSD) are much better for NP (1.13) than for TD (0.42).

To better understand the contrasting behaviour of the two LMDz versions here, we compare time series of process trends for the first half of April 2009 at Heidelberg (Fig. 5). Trends are expressed here in $\mathrm{Bq} \mathrm{m} \mathrm{m}^{-3} \mathrm{~h}^{-1}$. Similar trend daily cycles are clearly evident for each process. Vertical diffusion trends are positive from 18:00 to 08:00 UTC in NP. Indeed, with low nocturnal PBL height, vertical diffusion processes distribute the surface emitted radon throughout only a shallow layer resulting in a strong accumulation of radon near the surface. Vertical diffusion trends then become negative until 14:00 UTC. Indeed, the PBL starts to grow in the morning, with the increase in solar radiation, and radon accumulated near the surface over the previous night is mixed with low radon air from higher levels, resulting in lower sampled radon concentrations and a negative vertical diffusion trend. When radon is well-mixed throughout the PBL by the vertical diffusion processes, the vertical diffusion trend becomes positive again, since radon is emitted at the surface. The thermals scheme transports high levels of radon from the lower to upper levels from 08:00 to 18:00 UTC and it results in a negative contribution to the total trend. Deep convection processes do not transport any radon (convection trend is null), and the impact of advection on radon concentration at the Heidelberg station is generally insignificant.

For TD, the vertical diffusion trend is relatively similar to NP, although the magnitude of its diurnal cycle is $60 \%$ smaller. Indeed, maximum (minimum) of the vertical diffusion trend does not exceed $0.4 \mathrm{~Bq} \mathrm{~m}^{-3} \mathrm{~h}^{-1}$ (-0.5 Bq m${ }^{-3} \mathrm{~h}^{-1}$, respectively), while it reaches $0.8 \mathrm{~Bq} \mathrm{~m}^{-3} \mathrm{~h}^{-1}\left(-1.5 \mathrm{~Bq} \mathrm{~m}^{-3} \mathrm{~h}^{-1}\right)$ in the NP simulation. In TD, vertical diffusion trends are smaller leading to a lower accumulation of radon close to the surface. Indeed, the choice of the vertical diffusion scheme can have large impacts on the diurnal cycle amplitude: using the scheme of Yamada (1983) results in higher concentrations during the night as compared to Louis (1979). This is confirmed by a personal communication of F. Hourdin (2005) (Fig. S1 in Supplement), which shows that the ${ }^{222} \mathrm{Rn}$ diurnal cycle is sensitive to the choice of the diffusion scheme.

It is also shown that thermals have no major impact on the amplitude of ${ }^{222} \mathrm{Rn}$ diurnal cycle close to the surface at Heidelberg. However, thermals have a major impact on ${ }^{222} \mathrm{Rn}$ vertical profiles as it has been seen in Sect. 3.1. Indeed, thermals efficiently transport ${ }^{222} \mathrm{Rn} R^{2}$ at the top of the boundary layer (Fig. S2). Thus, this is the combination of the Yamada (1983) scheme and the thermal plume model of Hourdin et al. 

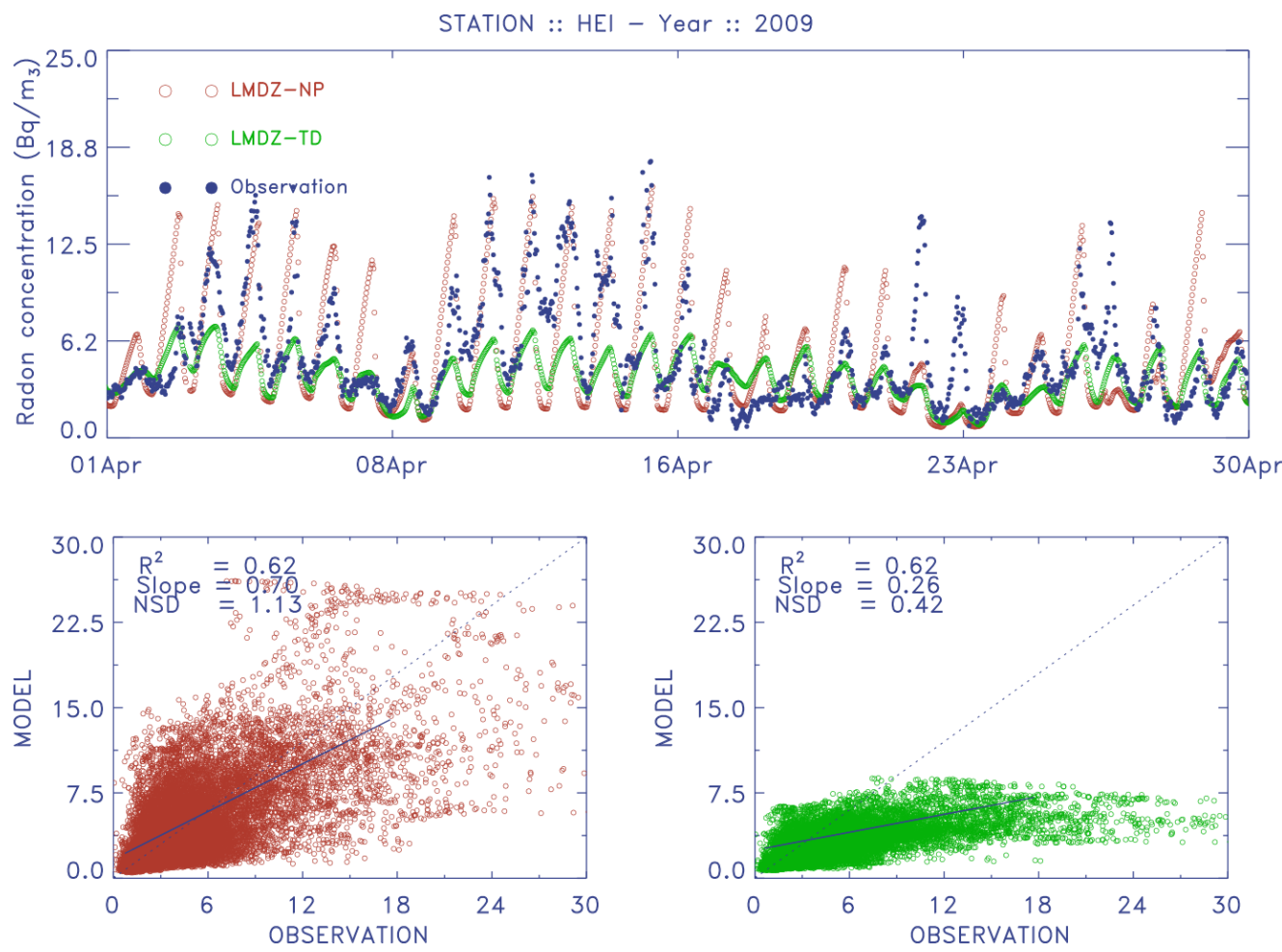

Figure 4. Time series of ${ }^{222} \mathrm{Rn}$ hourly concentrations at Heidelberg in April 2009. Red (Green and Blue) time series refer to NP simulation (TD simulation and observations, respectively). Scatter plots for NP and TD are also showed with main statistic diagnostics $\left(R^{2}\right.$, normalized standard deviation (NSD) and slope coefficient of the linear regression). NSD is the ratio between the standard deviation of simulated ${ }^{222} \mathrm{Rn}$ concentrations by the standard deviation of observed ${ }^{222} \mathrm{Rn}$ concentrations.
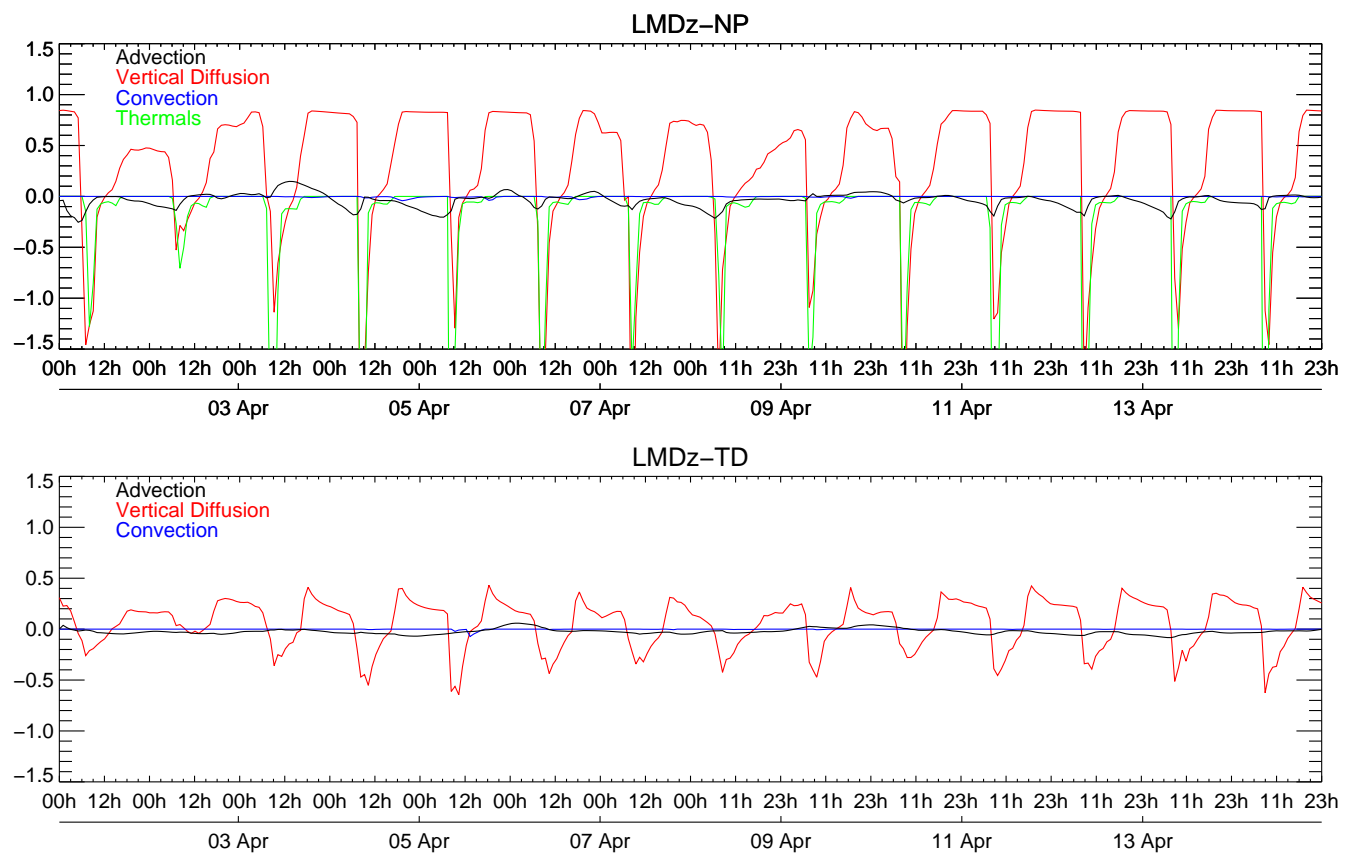

Figure 5. Time series of advection (black), vertical diffusion (red), convection (blue) and thermal (green) trends at Heidelberg station in the beginning of April 2009 for NP simulation (top) and TD simulation (bottom). The unit is $\mathrm{Bq} \mathrm{m}^{-3} \mathrm{~h}^{-1}$. 

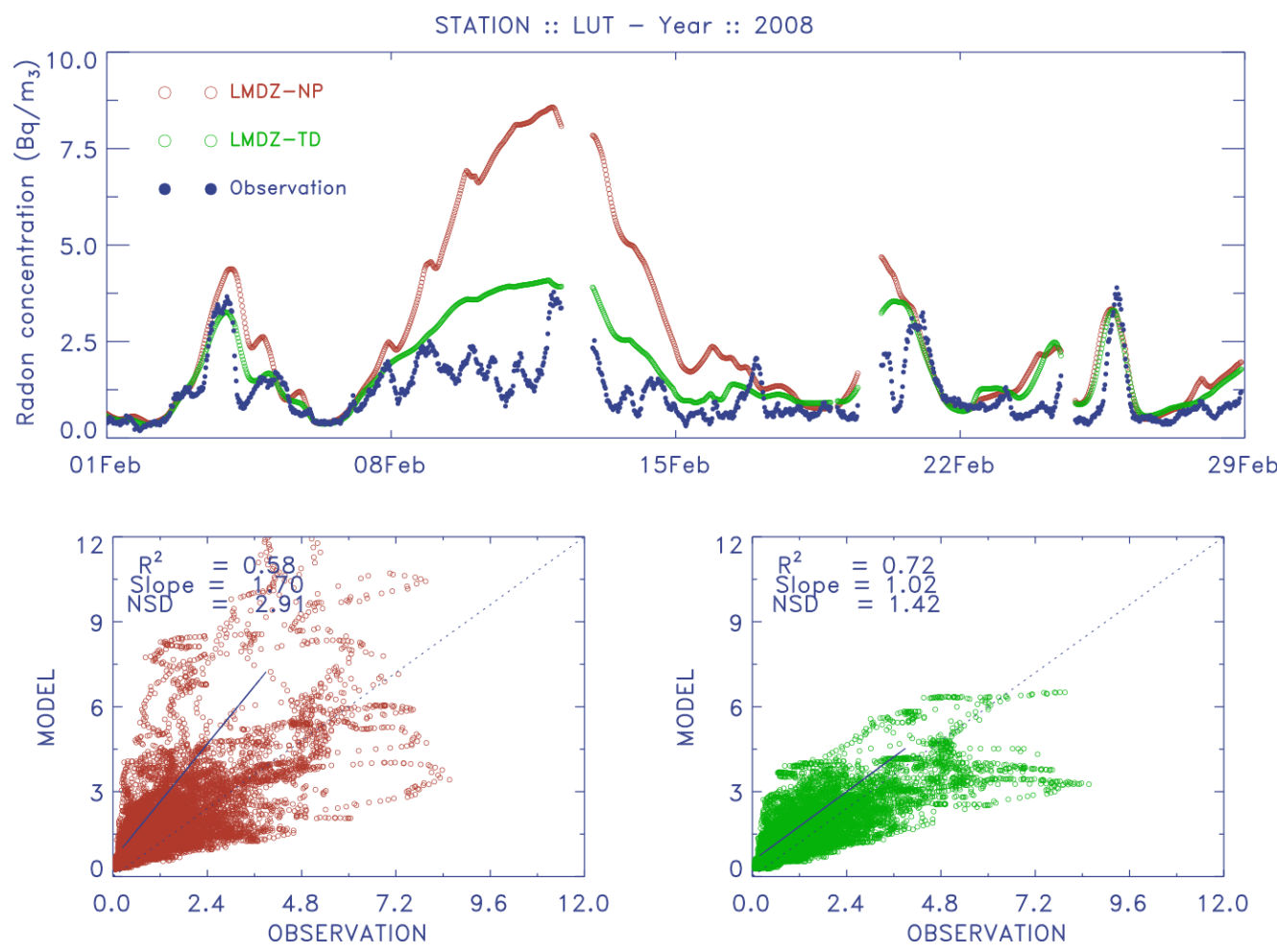

Figure 6. Time series of ${ }^{222} \mathrm{Rn}$ hourly concentrations at Lutjewad in February 2008. Red (Green and Blue) time series refer to NP simulation (TD simulation and observations, respectively). Scatter plots for NP and TD are also showed with main statistic diagnostics $\left(R^{2}\right.$, normalized standard deviation (NSD) and slope coefficient of the linear regression). NSD is the ratio between the standard deviation of simulated ${ }^{222}$ Rn concentrations by the standard deviation of observed ${ }^{222} \mathrm{Rn}$ concentrations.

(2002) which give good scores in the simulation of ${ }^{222} \mathrm{Rn}$ concentrations at Heidelberg.

Despite the differences noted above, $R^{2}$ statistics are equal in NP and TD ( 0.62 for the two simulations) for Heidelberg in April 2009 (Fig. 4, bottom). One factor contributing to $R^{2}$ values for NP lower than expected was that NP occasionally simulated peaks that were not observed as evident in Fig. 4 toward the end of April 2009, which strongly degrades the $R^{2}$ statistic in the NP case.

We now investigate this issue with the example of radon time series at Lutjewad in February 2008 (Fig. 6). Indeed, a peak reaching $9 \mathrm{~Bq} \mathrm{~m}^{-3}\left(4 \mathrm{~Bq} \mathrm{~m}^{-3}\right)$ is simulated by $\mathrm{NP}$ (TD respectively) between the 8 and 15 February, while smaller peaks are observed (around $3 \mathrm{~Bq} \mathrm{~m}^{-3}$ ). However, the analysis of physical process trends at Lutjewad for the same period (Fig. 7) is relatively similar to Heidelberg's analysis. To understand this apparent inconsistency, an analysis of nearsurface quantities has been performed. When 2-metre temperatures $\left(T_{2 \mathrm{M}}\right)$ simulated by TD and NP are compared with those obtained from the ERA-Interim product (Fig. 3 in supplementary materials), it is found that they are quite different (up to $7^{\circ} \mathrm{C}$ ) during the month of February 2008. Consequently, the PBL heights are probably very different between the models and the reanalysed data, and one can not expect any good scores for modelling of radon transport to Lutjewad during this period. Note that the same $T_{2 \mathrm{M}}$ cold bias is simulated by TD but with a much weaker impact on ${ }^{222} \mathrm{Rn}$ mole fraction. Indeed, NP simulates a peak twice bigger than the peak simulated by TD. This suggests that the sensitivity of the NP version is larger than in TD simulations (considering similar forcings).

We have also looked at surface characteristics for the Heidelberg case (Fig. S3). Both simulations (NP and TD) are able to reproduce the diurnal cycle of $T_{2 \mathrm{M}}$ given by ERAInterim product in April 2009. However, only ${ }^{222} \mathrm{Rn}$ simulated by NP is able to fit the strong ${ }^{222} \mathrm{Rn}$ diurnal cycle measured at Heidelberg in April 2009. This confirms again that responses in TD simulations are much smoother than in NP simulations.

\section{Modelling of large-scale atmospheric transport}

In this section, we investigate the ability of different $\mathrm{LMDz}$ versions to represent large-scale (e.g. inter-hemispheric and troposphere/stratosphere) trace gas exchanges. To do so, we focus on longer-lived species, such as the inert sulfur hexafluoride $\left(\mathrm{SF}_{6}\right)$ (Sects. 4.1, 4.2.1 and 4.3) or carbon dioxide $\left(\mathrm{CO}_{2}\right)$ (Sect. 4.2.2), and reactive methane $\left(\mathrm{CH}_{4}\right)($ Sect. 4.4). 

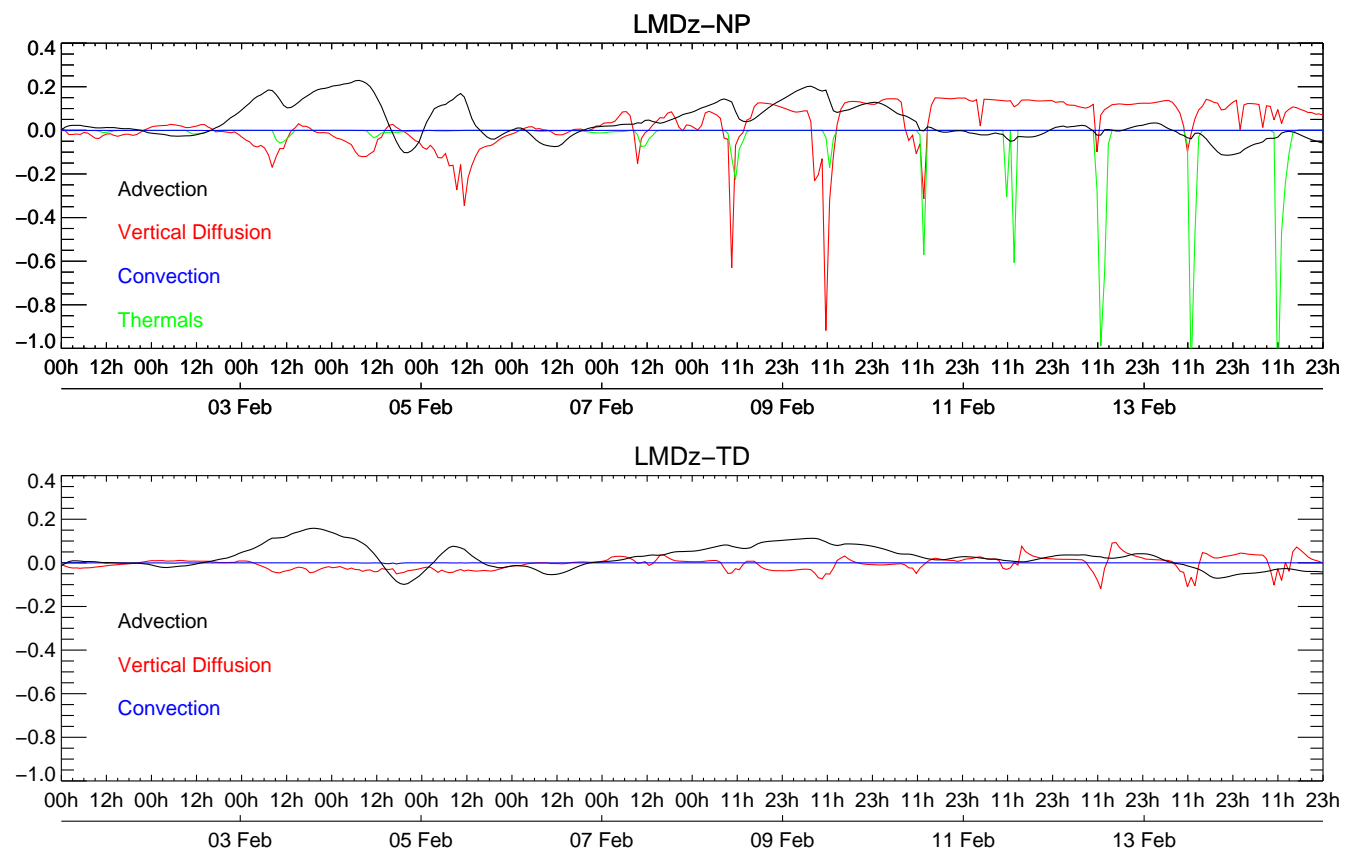

Figure 7. Time series of advection (black), vertical diffusion (red), convection (blue) and thermals (green) trends at Lutjewad station in the beginning of February 2008 for NP simulation (top) and TD simulation (bottom). The unit is Bq $\mathrm{m}^{-3} \mathrm{~h}^{-1}$.

\subsection{Large-scale transport features of $\mathrm{LMDz}$ configuration using $\mathrm{SF}_{6}$ simulations}

$\mathrm{SF}_{6}$ is an anthropogenic compound, which is mainly produced worldwide in the electrical industry (transformers, circuit breakers, etc.). Indeed, $\mathrm{SF}_{6}$ is used in equipment for electrical transmission and distribution systems and in the reactive metals industry (Maiss and Brenninkmeijer, 1998). According to EDGAR inventory (http://edgar.jrc.ec.europa.eu), $\mathrm{SF}_{6}$ global emissions reached 5.5 Gg in 2005. Moreover, $\mathrm{SF}_{6}$ has been widely used to study atmospheric transport (Denning et al., 1999; Law et al., 2008; Patra et al., 2009). Indeed, since it is inert, $\mathrm{SF}_{6}$ is very long-lived in the troposphere and stratosphere (between 800 to 3200 years; Ravishankara et al., 1993; Morris et al., 1995), which makes $\mathrm{SF}_{6}$ a powerful tool for assessing large-scale modelling of transport processes in the atmosphere (Maiss et al., 1996).

Here we employ monthly zonal averages of $\mathrm{SF}_{6}$ to investigate boundary layer mixing (mixing due to vertical diffusion in TD and SP, and mixing due to both vertical diffusion and thermal plumes in NP), convection and advection (unit is mass mixing ratio per month (pptm month $\left.{ }^{-1}\right)$ ) as modelled in LMDz for three different configurations of the model (NP, TD and SP, see Sect. 2). We choose to present results for a summer month (July, see Fig. 8) as convection intensity over locations where $\mathrm{SF}_{6}$ is mainly emitted (between $30^{\circ} 23^{\prime} \mathrm{N}$ and $60^{\circ} 23^{\prime} \mathrm{N}$ ) is maximum during summer. $\mathrm{SF}_{6}$ emission fields are taken from EDGAR v4.0 and scaled to Levin et al. (2010) as it has been done for the TransCom model intercomparison of Patra et al. (2011).
First of all, we detail the general transport pathway for the three configurations of LMDz. Vertical diffusion (including thermal plumes in NP) mixes $\mathrm{SF}_{6}$ from the surface throughout the boundary layer (Fig. 8, top). This is very clear between $30^{\circ} 23^{\prime} \mathrm{N}$ and $60^{\circ} 23^{\prime} \mathrm{N}$ where $\mathrm{SF}_{6}$ emissions are stronger. Above the boundary layer, vertical diffusion gradually reduces and vertical transport is mainly accomplished by deep convection (Fig. 8, middle), which moves $\mathrm{SF}_{6}$ from the boundary layer to the top of the troposphere $(\sim 200 \mathrm{hPa})$. The large positive convection trend area between $30^{\circ} 23^{\prime} \mathrm{N}$ and $60^{\circ} 23^{\prime} \mathrm{N}$ is consistent with the location of both strong convection area over continents and strong $\mathrm{SF}_{6}$ emissions at this period of the year. Then, tropospheric $\mathrm{SF}_{6}$ is advected from $30^{\circ} 23^{\prime}-60^{\circ} 23^{\prime} \mathrm{N}$ to $15^{\circ} 23^{\prime} \mathrm{S}-15^{\circ} 23^{\prime} \mathrm{N}$ band by meridional advection (Fig. 8, bottom). Finally, $\mathrm{SF}_{6}$ is transported from the high to the low levels of the troposphere by subsident motions forming the descending branch of the Hadley cell between $15^{\circ} 23^{\prime} \mathrm{S}$ and $5^{\circ} 23^{\prime} \mathrm{N}$ (blue plume on Fig. 8, middle).

General characteristics of large-scale transport look similar between model versions but we can wonder how the three configurations of the model (NP, TD and SP) differ. Looking at the transport in the boundary layer, the main difference is the height at which mixing due to vertical diffusion (and thermals for $\mathrm{NP}$ configuration) transports $\mathrm{SF}_{6}$. In $\mathrm{TD}$ or $\mathrm{SP}$, vertical diffusion processes transport $\mathrm{SF}_{6}$ up to $600 \mathrm{hPa}$, while in $\mathrm{NP} \mathrm{SF}_{6}$ is transported slightly higher, up to $500 \mathrm{hPa}$. If one splits the processes acting in the boundary layer for the $\mathrm{NP}$ configuration, one finds that vertical diffusion is mainly active from surface to $900 \mathrm{hPa}$ and thermals are responsible 


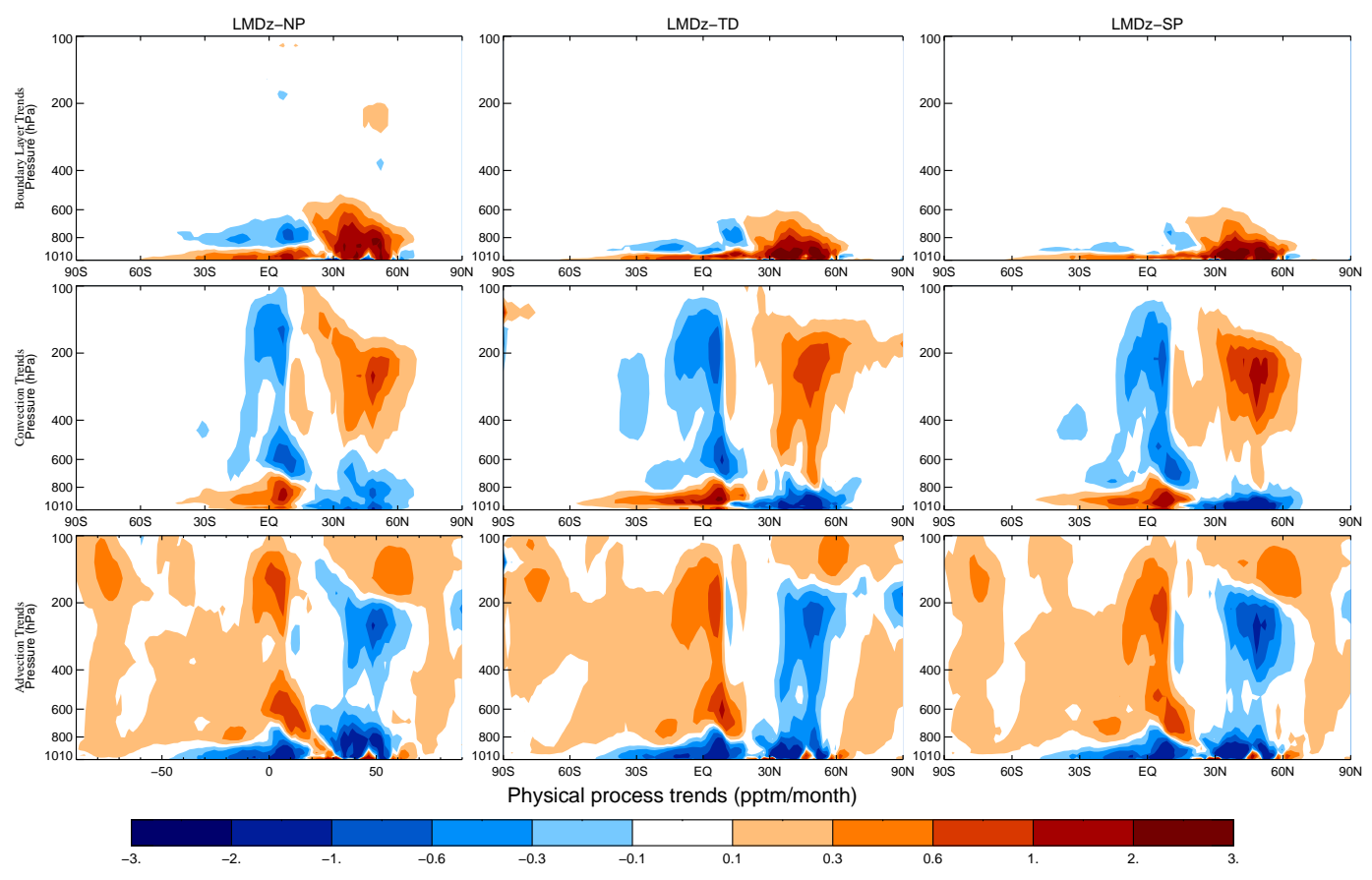

Figure 8. Zonal and monthly average of $\mathrm{SF}_{6}$ boundary layer (top row), convection (centre row) and advection (bottom row) trends (in pptm month ${ }^{-1}$ ) in July for NP (left column), TD (centre column) and SP (right column) simulations.

for $\mathrm{SF}_{6}$ transport in higher parts of the boundary layer as has been shown in Sect. 3.1. Moreover, when using the Tiedtke (1989) scheme (TD), convection transports $\mathrm{SF}_{6}$ across more layers than in the versions using Emanuel (1991) scheme (SP and NP). Indeed, detrainment of tracers by deep convection between 800 and $500 \mathrm{hPa}$ is almost non-existent in NP and $\mathrm{SP}$, while it is certainly not negligible in TD. One can also notice, by comparing positive convection trends over $40^{\circ} 23^{\prime} \mathrm{N}$ in NP and SP that the intensity of convection is weaker when the thermal plume model is activated, which can be expected.

\subsection{Inter-hemispheric exchange with $\mathrm{SF}_{6}$ and biospheric- $\mathrm{CO}_{2}$ simulations}

\subsection{1 $\mathrm{SF}_{6}$ simulations}

The inter-hemispheric (IH) exchange of trace gases simulated by CTMs is very valuable indicators of how atmospheric transport performs at the global scale. For example, Patra et al. (2011) compare the IH exchange time simulated by different CTMs with an indirectly measured exchange time using $\mathrm{SF}_{6}$ measurements. Their method use $\mathrm{SF}_{6}$ measurements at two stations of the Northern Hemisphere (Barrow (Alaska, USA) and Mauna Loa (Hawaii, USA) stations) and two stations of the Southern Hemisphere (Cape Grim (Australia) and South Pole stations) to derive the IH gradient. We tried to apply this method in our study. However we found that uncertainties related to the choice of stations and to the station sampling levels appeared to be larger than dif- ferences in IH exchange time simulated by the different configurations of LMDz. Consequently, we do not further discuss the IH exchange time, but we analyse the IH exchange by studying $\mathrm{SF}_{6}$ meridional gradients.

Annual means of $\mathrm{SF}_{6}$ surface mole fractions, zonally averaged and at 11 measurement sites, are plotted in Fig. 9a for five different configurations of LMDz. This view of the north-to-south $\mathrm{SF}_{6}$ surface gradient gives a direct indication of IH exchange. The NP, SP and TD configurations $(96 \times 96 \times 39)$ of $\mathrm{LMDz}$ are shown in red, blue and green respectively. We have also investigated the impact of a higher horizontal (TD-144 × $142 \times 39$, purple line) and a lower vertical (TD-96 $\times 72 \times 19$, orange line) resolution on IH exchange. The black diamonds show the measured $\mathrm{SF}_{6}$ mole fraction at different surface stations. The coloured crosses show the station value for the different model configurations. For better clarity, the results of the different simulations have been adjusted to equal the mean of $\mathrm{SF}_{6}$ mole fraction measured at the 11 surface stations. The adjustments are 0.69 , $0.68,0.70,0.71$ and $0.70 \mathrm{ppt}$ for respectively TD-39-96 $\times 96$, NP-39-96 × 96, TD-19-96 × 96, TD-39-144 × 142 and SP$39-96 \times 96$.

Knowing that the majority of $\mathrm{SF}_{6}$ emissions are located in the Northern Hemisphere, it is not surprising to see $\mathrm{SF}_{6}$ mole fraction shifting from $5.49 \mathrm{ppt}$ at the South Pole to $5.81 \mathrm{ppt}$ at Alert (Canada). The maximum of zonal mean $\mathrm{SF}_{6}$ mole fraction is reached at around $40^{\circ} 23^{\prime} \mathrm{N}$, close to the latitudes of maximum emissions. Figure 9a shows that simulated $\mathrm{SF}_{6}$ mole fractions in all $\mathrm{LMDz}$ configurations over- 

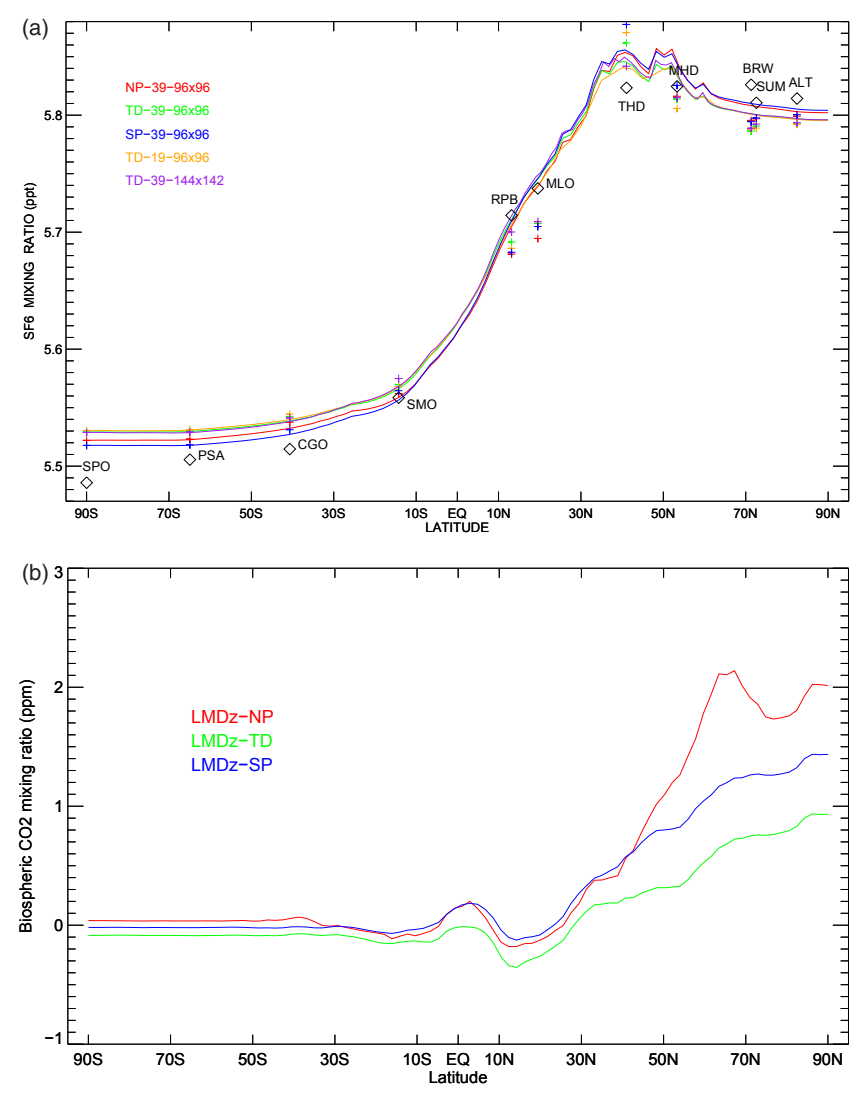

Figure 9. (a) Zonally averaged $\mathrm{SF}_{6}$ surface dry mole fraction (in ppt) for NP (red), TD (green) and SP (blue) configurations of LMDz using an horizontal resolution of 96 points in longitude by 96 points in latitude and with 39 vertical levels $(96 \times 96 \times 39)$. Others resolutions $(144 \times 142 \times 39$ in purple, and $96 \times 72 \times 19$ in orange $)$ have also been tested using TD configuration. Also shown are $\mathrm{SF}_{6}$ measurements (black crosses) at 11 surface stations coming from the NOAA/ESRL network (http://www.esrl.noaa.gov/gmd). (b) The rectifier effect. Surface zonal annual mean $\mathrm{CO}_{2}$ dry mole fractions (in ppm) resulting from biosphere emissions only. The concentrations have been reduced by the global January mean concentration.

estimate (under-estimate) $\mathrm{SF}_{6}$ measurements in the high latitudes of the Southern Hemisphere (in the very high latitudes of the Northern Hemisphere) confirming that $\mathrm{IH}$ exchange is too fast in LMDz (Patra et al., 2011). However, two configurations of LMDz, SP and NP, both using the deep convection scheme of Emanuel (1991), have a slightly steeper IH gradient $(\sim 8 \%)$, although still smaller than the observed IH gradient. The steeper vertical gradient in the lower part of the troposphere when using the Emanuel scheme could be an explanation. Indeed, the detrainment in the Emanuel (1991) scheme was smaller between 800 and $600 \mathrm{hPa}$ (Sect. 4.1) compared to the Tiedtke (1989) scheme. This leads to slightly steeper vertical gradient in the lower part of the troposphere as shown in Table 3, which summarizes the vertical gradient of $\mathrm{SF}_{6}$ between 900 and $500 \mathrm{hPa}$ for the different physical sets of parameterizations used in
Table 3. $\mathrm{SF}_{6}$ vertical gradient in $\mathrm{ppt} \mathrm{km}^{-1}$ between $900 \mathrm{hPa}$ $(\sim 1 \mathrm{~km})$ and $500 \mathrm{hPa}(\sim 4 \mathrm{~km})$ for the three configurations of LMDz (TD, SP and NP).

\begin{tabular}{lccc}
\hline & TD & SP & NP \\
\hline January & 0.021 & 0.022 & 0.022 \\
April & 0.021 & 0.026 & 0.023 \\
July & 0.011 & 0.013 & 0.013 \\
October & 0.020 & 0.024 & 0.022 \\
\hline
\end{tabular}

LMDz. This is consistent with Saito et al. (2013) who show that latitudinal gradients in a CTM are generally proportional to the vertical gradients in the lower troposphere. Furthermore, vertical transport by thermals reduces vertical gradient in NP compared to SP in the first layers of the troposphere, which may explain the slightly smaller IH gradient computed in NP compared to SP. Furthermore, we find similar IH gradients when using different vertical and/or horizontal resolution with the TD version of LMDz. On the contrary, Patra et al. (2011) found slight differences between IH exchange time of high and low horizontal resolution versions of two CTMs. However, the gap between the high and the low horizontal resolutions (from $6^{\circ} 23^{\prime} \times 4^{\circ} 23^{\prime}$ to $1^{\circ} 23^{\prime} \times 1^{\circ} 23^{\prime}$ and from $5^{\circ} 23^{\prime} \times 4^{\circ} 23^{\prime}$ to $1.25^{\circ} 23^{\prime} \times 1^{\circ} 23^{\prime}$ ) of the CTMs used in their study is much larger that the gap used here (from $1.875^{\circ} 23^{\prime} \times 3.75^{\circ} 23^{\prime}$ to $1.25^{\circ} 23^{\prime} \times 2.5^{\circ} 23^{\prime}$ ).

Overall, $\mathrm{SF}_{6}$ latitudinal gradient differences among the different configurations of LMDZ reach $0.03 \mathrm{ppt}$, the maximum (minimum) latitudinal gradient being $0.29 \mathrm{ppt}$ for SP (0.26 ppt for TD-19) in our study, while in Denning et al. (1999) the $\mathrm{SF}_{6}$ latitudinal gradients simulated by different CTMs exhibit differences up to $0.2 \mathrm{ppt}$. This suggests that modifications in sub-grid scale parameterizations of LMDz cause only small differences in IH transport characteristics for $\mathrm{SF}_{6}$.

\subsubsection{Biospheric- $\mathrm{CO}_{2}$ simulations}

Meridional transport may not be the only cause for IH gradient of trace gases. Indeed, the so-called rectifier effect, introduced by Denning et al. (1995), is one cause for the existence of meridional gradient of biospheric $\mathrm{CO}_{2}$ mole fraction. The seasonal rectifier effect is the consequence of the correlation between the atmospheric transport in the PBL and the surface biospheric $\mathrm{CO}_{2}$ flux. Indeed, both atmospheric turbulence and the flux of $\mathrm{CO}_{2}$ from the biosphere to the atmosphere undergoes a seasonal cycle. During winter, at mid to high latitudes, microbial respiration dominates photosynthesis leading to net $\mathrm{CO}_{2}$ emissions to the atmosphere. Moreover, stable atmospheric conditions are predominant in winter. It results higher $\mathrm{CO}_{2}$ mole fractions at the surface than if no correlation occurs. On the contrary, during summer, photosynthesis is dominating upon respiration and unstable atmospheric conditions prevail, leading to the dilution of the 
net flux from atmosphere to land by strong turbulence. In summer, PBL depth can reach $2 \mathrm{~km}$ above mid-latitude continents at midday (Seidel et al., 2012). It results lower mole fractions at the surface than if no correlation occurs. Consequently, on an annual basis, even if global biospheric $\mathrm{CO}_{2}$ emissions are set to zero, a meridional gradient can be generated with higher mole fractions in the Northern Hemisphere than in the Southern Hemisphere, especially above northern continental regions, such as Siberia (Denning et al., 1995).

The Fig. $9 \mathrm{~b}$ displays the impact of this rectifier effect on the meridional $\mathrm{CO}_{2}$ gradient by showing surface zonal annual mean $\mathrm{CO}_{2}$ mole fraction due to biosphere exchange only, as simulated by three configurations of LMDZ (NP, SP and TD in red, blue and green). We use CASA fluxes with monthly resolution and a zero annual mean flux everywhere coming from Randerson et al. (1997) to represent biospheric emissions. Each plot has been reduced by the global January mean $\mathrm{CO}_{2}$ mole fraction. NP, SP and TD versions of $\mathrm{LMDz}$ respectively simulate a $\mathrm{CO}_{2}$ meridional gradient reaching 1.8, 1.6 and $1.0 \mathrm{ppm}$ between South and North Pole. These gradients are in agreement with what was previously found on the rectifier effect in the TransCom experiment (Law et al., 1996; Gurney et al., 2003). Indeed, the range of meridional biospheric $\mathrm{CO}_{2}$ gradient among chemistry-transport models spread from 0 to $3.5 \mathrm{ppm}$ both in Law et al. (1996) and Gurney et al. (2003). In Law et al. (1996), model results can be clustered in two groups: one group of models simulating seasonal rectifier around $0.5 \mathrm{ppm}$ and one other group with rectifier around 2 ppm. In Gurney et al. (2003), simulated rectifier effects are much more spread between 0 and $3 \mathrm{ppm}$. From these two studies, one can conclude that NP simulating a rectifier effect of $1.8 \mathrm{ppm}$ is in the higher part of the range since only 4 CTMs (over a total of 17 different CTMs) simulate a stronger rectifier effect. On the contrary, TD simulating a rectifier effect of $1.0 \mathrm{ppm}$ is in the lower part since only 6 CTMs simulate a weaker rectifier effect.

Furthermore, it is noticeable to see that the different configurations of $\mathrm{LMDz}$ simulate oscillations in $\mathrm{CO}_{2}$ mole fraction around $5^{\circ} 23^{\prime} \mathrm{N}$ (Fig. 9b), which is a consequence of the correlation between the seasonal shift of the Intertropical Convergence Zone (ITCZ) and biosphere flux in the Tropics. It is also interesting to note that LMDz-NP and LMDz-SP give similar results in the Tropics and large differences from $45^{\circ} 23^{\prime} \mathrm{N}$. Knowing that LMDz-NP and LMDz-SP use the same deep convection mixing scheme and that deep convection is the main contributor to vertical mixing in the Tropics, it is not surprising to have similar results in these regions. However, in extratropics regions of the Northern Hemisphere vertical diffusion and mixing due to thermals have a significant impact on biospheric $\mathrm{CO}_{2}$ mixing, especially over Siberia (not shown), where most of the rectifier applies in LMDz. Moreover, magnitudes of physical trends due to vertical diffusion and thermals can be highly different between LMDz-NP and LMDz-SP at these latitudes, which explains why these two configurations of LMDz simulate significantly different rectifier effects.

Unfortunately, large uncertainties still exist on the knowledge of the magnitude and of the spatial distribution of the actual rectifier effect. Indeed, observations of covariance signals between $\mathrm{CO}_{2}$ flux and PBL mixing are lacking. Few studies have attempted to directly measure rectifier effects (Yi et al., 2004; Chen et al., 2004; Stephens et al., 2013). Although these studies bring very valuable knowledge on the rectifier effect at local scales, they do not allow to draw conclusions on the magnitude of the rectifier effect at the global scale. In fact, Yi et al. (2004) compare the rectifier effect simulated by the CSU GCM (Colorado State University GCM) with observed rectifier forcing at a specific station in northern Wisconsin (USA). They conclude that the observed seasonal covariance between ecosystem $\mathrm{CO}_{2}$ fluxes and PBL turbulent mixing are stronger than the same signals simulated by the CSU GCM. Chen et al. (2004) developed a Vertical Diffusion Scheme (VDS) to investigate the rectifier effect and to validate their model with measurements at Fraserdale, Ontario (Canada). They conclude that the seasonal rectifier effect contributes largely to the total rectifier effect: $75 \%$ of the total rectifier effect is due to the seasonal rectifier effect, while the rest is caused by the diurnal rectifier effect. Moreover, Stephens et al. (2007) argue for a weak seasonal rectifier effect (see Fig. 7 in Supplementary Materials of Stephens et al., 2007).

Finally, one can hardly conclude from these incomplete pieces of information which version of LMDz better simulates the rectifier effect. However, these differences in the representation of the rectifier effect will definitely have large impacts on inverse estimates (see Sect. 5). Moreover, large efforts have been recently made to provide a global PBL climatology based on observations (Seidel et al., 2012; McGrath-Spangler and Denning, 2013), which could also give valuable information on the PBL mixing. Thus, from such approaches, an observation-driven estimation of the actual magnitude of the rectifier effect could emerge soon, which will be very interesting for future evaluation of CTMs.

\subsection{Stratosphere/troposphere exchange (STE) using long-lived species}

Exchanges between the stratosphere and troposphere may have large impacts on atmospheric concentrations of trace gases (Holton et al., 1995). Thompson et al. (2014) show that it is especially true for $\mathrm{N}_{2} \mathrm{O}$ since the major part of $\mathrm{N}_{2} \mathrm{O}$ sink is located in the stratosphere (photolysis and oxidation by $\mathrm{O}^{1} \mathrm{D}$ ). Moreover, Thompson et al. (2014) compare the atmospheric distribution of $\mathrm{N}_{2} \mathrm{O}$ as simulated by different CTMs with a focus on the representation of STE. They show that the Brewer-Dobson circulation is poorly simulated by LMDz, which badly resolves seasonal influence of STE on $\mathrm{N}_{2} \mathrm{O}$ mole fractions. In Patra et al. (2011), focusing on $\mathrm{CH}_{4}$ simulations, LMDz is also pointed out to simulate STE that 
Table 4. Percentage (\%) of the total atmospheric $\mathrm{SF}_{6}$ burden computed in four boxes (Troposphere in the Southern Hemisphere, troposphere in the Northern Hemisphere, stratosphere in the Southern Hemisphere and stratosphere in the Northern Hemisphere) for two LMDz configurations using 39 levels (NP-39 and TD-39) and one another using 19 levels (TD-19).

\begin{tabular}{cccc}
\hline & & $\begin{array}{c}\text { Southern } \\
\text { Hemisphere }\end{array}$ & $\begin{array}{c}\text { Northern } \\
\text { Hemisphere }\end{array}$ \\
\hline \multirow{3}{*}{ Stratosphere } & NP-39 & $7.4 \%$ & $7.4 \%$ \\
& TD-39 & $7.4 \%$ & $7.5 \%$ \\
& TD-19 & $10.8 \%$ & $10.9 \%$ \\
\hline \multirow{5}{*}{ Troposphere } & NP-39 & $41.8 \%$ & $43.4 \%$ \\
& TD-39 & $41.8 \%$ & $43.4 \%$ \\
& TD-19 & $38.4 \%$ & $39.9 \%$ \\
\hline
\end{tabular}

is too fast compared to others CTMs with a wrong position of the tropopause (especially in the Tropics). These results presented in Thompson et al. (2014) and Patra et al. (2011) have been obtained using the physical parameterizations of TD configuration and with a low vertical resolution (19 levels). These two studies clearly identify the low vertical resolution of LMDz as a factor responsible for the poor STE representation. Moreover, Hourdin et al. (2013a), studying the impact of LMDz grid configuration on the climate, have shown that a higher vertical resolution (especially with more vertical layers in the stratosphere) leads to a better representation of stratospheric variability. Thus, one can hypothesize that by increasing the number of model layers from 19 to 39, with especially more layers in the PBL and above the tropopause, the model will better simulate exchange at the transition between troposphere and stratosphere.

To investigate this statement, we present comparisons of the $\mathrm{SF}_{6}$ burden computed for four boxes (stratosphere and troposphere in the Northern and Southern Hemisphere) between two LMDz 39-layer versions (NP-39 and TD-39) and one LMDz version using only 19 vertical layers (TD-19). The limit between stratosphere and troposphere has been set at $150 \mathrm{hPa}$ in all simulations. Knowing that $\mathrm{SF}_{6}$ is very wellmixed in the troposphere and in the stratosphere, one can evaluate STE efficiency by comparing the $\mathrm{SF}_{6}$ burden (Table 4).

First of all, it is found that differences between versions using different vertical resolutions are much larger than differences between LMDz versions using the same vertical resolution but different physical parameterizations. Indeed, it is found that $10.9 \%$ of total $\mathrm{SF}_{6}$ atmospheric burden is present in the stratosphere of the Northern Hemisphere for TD-19, while only 7.4 and $7.5 \%$ is found in NP-39 and TD-39 simulations respectively. On the contrary, the $\mathrm{SF}_{6}$ atmospheric burden for NP-39 (43.4\%) and TD-39 (43.3\%) is larger in the troposphere of the Northern Hemisphere compared to TD-19 (39.9\%). Similar results are found for the Southern
Hemisphere. Therefore exchange between the troposphere and stratosphere is slowed down with 39-layer configurations of LMDz, which improves the flaw of LMDz regarding STE representation.

Moreover, we have computed the tropopause height using the method described in Reichler et al. (2003). Thus, the tropopause height is defined as the height at which the temperature lapse rate becomes less than $2 \mathrm{~K} \mathrm{~km}^{-1}$. This is also the approach used in Thompson et al. (2014). We find that TD-19, TD-39, SP-39 and NP-39 simulate tropopause height in the Tropics at 109, 105, 106 and $106 \mathrm{hPa}$ respectively, which is consistent with the results found in Thompson et al. (2014). Indeed, they computed the tropopause height for eight CTMs and they found that the tropopause height ranged from 101 to $106 \mathrm{hPa}$ for seven CTMs, while the tropopause height computed using LMDz (TD-19 configuration) was an outlier since it reached $109 \mathrm{hPa}$. Consequently, by improving vertical resolution from 19 to 39 levels, the tropopause height simulated by LMDz falls into the range of seven CTMs simulating quite well STE (Thompson et al., 2014). Moreover, we assess here also that modifications on the vertical resolution impact the location of the tropopause height much more than modifications on physical parameterizations.

Finally, these different results confirm that STE is slowed down in LMDz configurations using a finer vertical resolution (39 versus 19 vertical levels), which goes in the good direction. However, a validation of the new STE is necessary and will be performed in a future work.

\subsection{Reactive species}

Changes in parameterizations of atmospheric processes in GCMs can also affect atmospheric chemistry (Mahowald et al., 1995). Indeed, Tost et al. (2010) have shown that the use of different sub-grid scale schemes affects atmospheric chemistry by changing both the meteorology (for example, modification of convection intensity) and chemistry (for example, modifications in location of the photochemical reactions). These different impacts on atmospheric chemistry cannot be tested with a passive tracer such as $\mathrm{SF}_{6}$. Thus, we analyse now the impact of changes in the LMDz model on atmospheric methane $\left(\mathrm{CH}_{4}\right)$, a long-lived reactive greenhouse gas, which is mainly oxidized by hydroxyl radical $(\mathrm{OH})$ in the troposphere (Kirschke et al., 2013). We ran simulations with the different configurations of LMDz to test this question.

Figure 10 shows 39 years of daily $\mathrm{CH}_{4}$ mole fraction averaged at global scale and over the first layers of the atmosphere (between surface and $850 \mathrm{hPa}$ ) for TD, NP and SP configurations. The exact same setup is used for these simulations (climatological $\mathrm{CH}_{4}$ emissions of $500 \mathrm{Tg} \mathrm{CH}_{4}$ year $^{-1}$, climatological oxidant fields and surface initial mean mole fraction of $1650 \mathrm{ppb}$ ). In the three simulations, the time series of $\mathrm{CH}_{4}$ mole fraction exhibit typical seasonal cycles each year with a low during boreal summer 


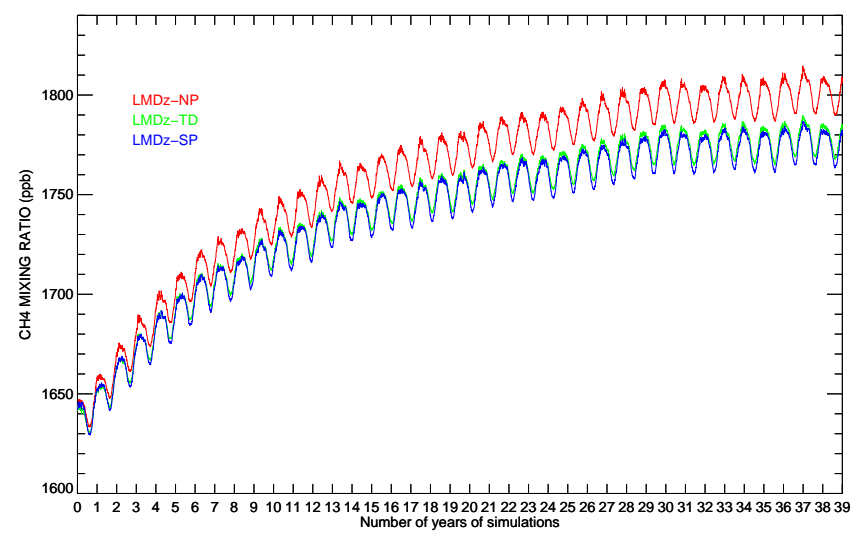

Figure 10. Time series of global-mean $\mathrm{CH}_{4}$ dry mole fraction averaged between the surface and $850 \mathrm{hPa}$, for NP (red), SP (blue) and TD (green) for 39 years of simulation. Identical initial value (1650 ppb for $\mathrm{CH}_{4}$ at the surface) and constant flux (500 Tg of $\mathrm{CH}_{4}$ per year) are used in these simulations.

and a high during boreal winter. Simulated seasonal cycles are very consistent between the three LMDz configurations. As emissions and sinks are climatological, $\mathrm{CH}_{4}$ global mole fraction tends to reach a steady state. Indeed, TD and SP simulations of annual $\mathrm{CH}_{4}$ mole fraction tend to reach 1778 and $1775 \mathrm{ppb}$ respectively after 30 years of simulations. The NP version, however, diverges from the SP and TD versions, with a steady state value of $1801 \mathrm{ppb}$ being reached, around $25 \mathrm{ppb}$ higher than TD and SP configurations. Thus, the use of different deep convection schemes does not look to be responsible for such differences in $\mathrm{CH}_{4}$ state equilibrium. Indeed, the TD and SP configurations give similar results. Consequently, one can infer that in this study the difference is due to the implementation of the thermal plume model, which contributes to perturbing the chemical equilibrium of $\mathrm{CH}_{4}$. In other words, the methane lifetime increases when the thermal plume scheme is activated. This increase has been assessed to be 0.2 years ( $2 \%$ of the typical methane lifetime; Naik et al., 2013).

We further investigate the difference between TD/SP and NP $\mathrm{CH}_{4}$ mole fractions. The chemical loss of methane is the product of a reaction rate $k_{\mathrm{CH}_{4}}, \mathrm{OH}$ concentrations and $\mathrm{CH}_{4}$ mole fraction. After investigation, we found that the difference of chemical equilibrium is mainly explained by the difference in the reaction rate, $k_{\mathrm{CH}_{4}}$, which is lower in the mid-troposphere for NP compared to SP and TD. Indeed, the reaction rate depends on tropospheric temperature according to the Arrhenius law $\left(k_{\mathrm{CH}_{4}}=A \times \exp (-B / T)\right.$, with $A=2.45 \times \exp (-12) \mathrm{s}^{-1}$ and $B=1775$ Kelvin in the case of methane). The cold temperature bias found in NP compared to SP and TD, as already shown in Hourdin et al. (2006), leads to a smaller consumption of methane by $\mathrm{OH}$ in the mid-troposphere for NP compared to SP and TD. In response, $\mathrm{CH}_{4}$ steady-state mole fraction is higher in the NP configuration. Furthermore, this effect is amplified since the difference between the reaction rate for NP and TD is at a maximum around $700 \mathrm{hPa}$, where $\mathrm{OH}$ mole fractions are also maximum.

\section{Conclusions and implications for inverse modelling of trace gas emissions and sinks}

We have investigated impacts of new physical parameterizations for deep convection (Emanuel, 1991) and boundary layer mixing due to vertical diffusion (Yamada, 1983) and thermal plumes (Rio and Hourdin, 2008; Rio et al., 2009) recently implemented in the LMDz GCM on atmospheric transport and chemistry of different trace gases. First, a comparison between a one-dimensional version of LMDz and a large eddy simulation of Meso-NH shows that the atmospheric transport of a short-lived tracer is greatly improved by the activation of the thermal plume model in a case of shallow convection over land. The combination of the deep convection scheme (Tiedtke, 1989) and vertical diffusion parameterizations (Louis, 1979) used in previous version of LMDz does not produce satisfactory results in the modelling of a growing boundary layer. Three-dimensional simulations of ${ }^{222} \mathrm{Rn}$, a tracer of surface continental air masses, confirm an overall improvement in PBL dynamics when the new parameterizations for vertical diffusion and thermal plumes are implemented. In particular, the amplitude and phase of the diurnal radon signal is found to be much better reproduced when the thermal plume model combined with the Yamada (1983) scheme are used. However, the higher variability of concentrations found in NP simulations increase the sensitivity of the results to external meteorological forcings.

These results for the PBL are encouraging for future atmospheric inversions of greenhouse gas emissions. When integrated in our inversion framework, this new version of $\mathrm{LMDz}$ will allow us to assimilate a larger fraction of the highfrequency data (daily, and maybe hourly) sampled at surface stations located close to source areas, which often show large peaks of concentrations on hourly to weekly timescales. Such data is not well simulated by the previous version of LMDzSACS and therefore are either removed or associated with a very large uncertainty in the inverse procedure. However, the higher sensitivity of NP version to the external forcing (see Sect. 3.2.2) may cause inadequate optimized fluxes if observation errors integrated into the inverse system are not consistently estimated. Indeed, one outcome of this work is that the transport model part of the observation error used for one observation in the inversion can largely depend on the configuration of the model used. Furthermore, a comparison of observation errors integrated into three different inverse systems for methane flux estimation has shown that observation errors are often under-estimated which exacerbate the impact of transport model errors on optimized fluxes (Locatelli et al., 2013). Thus, it will be essential to put a lot of attention on the estimation of observation errors when con- 
figuring the PYVAR inversion system with the new version of LMDz model. In particular, regardless of methods used to compute observation errors (statistical Berchet et al., 2013; Ganesan et al., 2014 or proxy Bergamaschi et al., 2010), one needs to check afterwards if errors are consistent with the capabilities of the model to reproduce the observations.

The skill of LMDz to represent large-scale transport has also been studied using a long-lived trace gas $\left(\mathrm{SF}_{6}\right)$. General transport pathways show similar behaviours between the different configurations of LMDz studied here. However, few differences are noticeable. First, it is shown that the use of the Emanuel deep convection scheme results in a small increase in the $\mathrm{IH} \mathrm{SF}_{6}$ gradient, although the gradient simulated by the NP version of LMDz is still too weak compared to observations. Moreover, the combination of thermal plume model with the Emanuel scheme in LMDz-NP leads to a stronger rectifier effect compared to LMDz-TD. Second, the stratosphere/troposphere exchange is largely improved by an increase in the vertical resolution (from 19 to 39 layers). Third, the thermal plume model plays an indirect role on the atmospheric loss of reactive species by modifying the vertical tropospheric temperature distribution which has a significant impact on reaction rates, and therefore on the lifetime of reactive compounds such as methane.

In global inversions, these changes in large-scale transport have large impacts on the derived fluxes. For example, IH exchange is fundamental to derive reasonable balance between Northern and Southern Hemisphere emissions. In particular, Locatelli et al. (2013) have shown that CTMs with IH exchange time that is too fast, as is the case with the TD version of LMDz, derive methane emissions with positive (negative) bias in the Northern (Southern) Hemisphere. Here, configurations of LMDz using the Emanuel scheme (NP and SP) simulate IH exchange slightly slower than the old version of LMDz. As a consequence, we expect to derive smaller IH gradient in inversions using NP and SP, which bring inverse estimate in the good direction. Additionally, it has been found that the rectifier effect, which mainly impacts $\mathrm{CO}_{2}$, is stronger in NP. Thus, a larger mid-latitude $\mathrm{CO}_{2}$ sink and a weaker tropical source are expected to be found by the inverse system using NP configuration (Stephens et al., 2007; Gurney et al., 2002). Moreover, tropospheric reactive gas distributions, which can be affected by stratosphere/troposphere exchange (such as $\mathrm{N}_{2} \mathrm{O}$; Thompson et al., 2014), are expected to be improved. As a consequence, inversions based on tropospheric measurements of these gases are expected to derive fluxes, which are not biased by a poor modelling of stratosphere/troposphere exchange.

Moreover, assimilation of constraints on the vertical profile (aircraft profiles, total-column satellite data, etc.) should less suffer from any potential biases related to the modelling of high-tropospheric/low-stratospheric concentrations.

Changes in modelled atmospheric lifetimes exhibited by reactive species like methane could lead to new biases in atmospheric concentrations, potentially influencing flux esti- mates from inversion studies. One could consider that a very slight nudging of temperature could reduce this bias. However, this possibility may be moderated by the risk of partly removing convection mixing when stabilizing the temperature profile and by the fact that the $\mathrm{OH}$ mean value is also poorly known (Prinn et al., 2005; Montzka et al., 2011): the bias in reaction falls within the large uncertainty range of the mean OH concentration (Naik et al., 2013).

Finally, this work has been driven by the need to reduce the impact of transport model errors in global inversions for estimation of greenhouse gas emissions and sinks. Such efforts are required in order to avoid a situation where CTM weaknesses become the main limiting factor in the reduction of uncertainties in the estimates of greenhouse gas emissions.

\section{Code availability}

The Fortan code of LMDz model is available from the following website: http://web.lmd.jussieu.fr/trac/browser/. General information on the way to install the LMDz model can be found at http://lmdz.lmd.jussieu.fr/. Additional information can be addressed to the correspondence author (robin.locatelli@1sce.ipsl.fr).

\section{The Supplement related to this article is available online at doi:10.5194/gmd-8-129-2015-supplement.}

Acknowledgements. Robin Locatelli is supported by DGA (Direction Générale de l'Armement) and by CEA (Centre à l'Energie Atomique et aux Energies Alternatives). The LMDz simulations were done using computing resources provided by the CCRT/GENCI computer centre of the CEA. We would like to thank Rebecca Fisher, Ingeborg Levin, Juha Hatakka and Ernst Brunke for their contributions to produce measurements of radon-222 at Egham, Heidelberg, Pallas and Cape Point stations. We would also like to thank Frédéric Chevallier for fruitful discussions.

Edited by: F. O'Connor 


\section{References}

Aydin, M., Verhulst, K. R., Saltzman, E. S., Battle, M. O., Montzka, S. A., Blake, D. R., Tang, Q., and Prather, M. J.: Recent decreases in fossil-fuel emissions of ethane and methane derived from firn air, Nature, 476, 198-201, doi:10.1038/nature10352, 2011.

Ayotte, K. W., Mcwilliams, J. C., Otte, M. J., Tribbia, J. J., and Wyngaard, J. C.: An evaluation of neutral and convective planetary boundary-layer parameterizations relative to large eddy simulations, Bound.-Lay. Meteorol., 79, 131-175, 1996.

Belikov, D. A., Maksyutov, S., Krol, M., Fraser, A., Rigby, M., Bian, H., Agusti-Panareda, A., Bergmann, D., Bousquet, P., Cameron-Smith, P., Chipperfield, M. P., Fortems-Cheiney, A., Gloor, E., Haynes, K., Hess, P., Houweling, S., Kawa, S. R., Law, R. M., Loh, Z., Meng, L., Palmer, P. I., Patra, P. K., Prinn, R. G., Saito, R., and Wilson, C.: Off-line algorithm for calculation of vertical tracer transport in the troposphere due to deep convection, Atmos. Chem. Phys., 13, 1093-1114, doi:10.5194/acp-131093-2013, 2013.

Berchet, A., Pison, I., Chevallier, F., Bousquet, P., Conil, S., Geever, M., Laurila, T., Lavrič, J., Lopez, M., Moncrieff, J., Necki, J., Ramonet, M., Schmidt, M., Steinbacher, M., and Tarniewicz, J.: Towards better error statistics for atmospheric inversions of methane surface fluxes, Atmos. Chem. Phys., 13, 7115-7132, doi:10.5194/acp-13-7115-2013, 2013.

Bergamaschi, P., Krol, M., Meirink, J. F., Dentener, F., Segers, A., van Aardenne, J., Monni, S., Vermeulen, A. T., Schmidt, M., Ramonet, M., Yver, C., Meinhardt, F., Nisbet, E. G., Fisher, R. E., O'Doherty, S., and Dlugokencky, E. J.: Inverse modeling of European $\mathrm{CH}_{4}$ emissions 2001-2006, J. Geophys. Res., 115, D22309, doi:10.1029/2010JD014180, 2010.

Bergamaschi, P., Houweling, S., Segers, A., Krol, M., Frankenberg, C., Scheepmaker, R. A., Dlugokencky, E., Wofsy, S. C., Kort, E. A., Sweeney, C., Schuck, T., Brenninkmeijer, C., Chen, H., Beck, V., and Gerbig, C.: Atmospheric $\mathrm{CH}_{4}$ in the first decade of the 21st century: Inverse modeling analysis using SCIAMACHY satellite retrievals and NOAA surface measurements, J. Geophys. Res., 118, 7350-7369, doi:10.1002/jgrd.50480, 2013.

Biraud, S., Ciais, P., Ramonet, M., Simmonds, P., Kazan, V., Monfray, P., O’Doherty, S., Spain, T. G., and Jennings, S. G.: European greenhouse gas emissions estimated from continuous atmospheric measurements and radon-222 at Mace Head, Ireland, J. Geophys. Res., 105, 1351-1366, doi:10.1029/1999jd900821, 2000.

Bougeault, P. and Lacarrère, S.: Parameterization of orographyinduced turbulence in a meso-beta scale model, Mon. Weather Rev., 117, 1870-1888, 1989.

Bousquet, P. and Ciais, P.: Inverse modeling of annual atmospheric $\mathrm{CO}_{2}$ sources and sinks: 1 . Method and control inversion, J. Geophys. Res., 104, 26179-26193, 1999.

Bousquet, P., Ciais, P., Miller, J. B., Dlugokencky, E. J., Hauglustaine, D. A., Prigent, C., Van der Werf, G. R., Peylin, P., Brunke, E.-G., Carouge, C., Langenfelds, R. L., Lathière, J., Papa, F., Ramonet, M., Schmidt, M., Steele, L. P., Tyler, S. C., and White, J.: Contribution of anthropogenic and natural sources to atmospheric methane variability, Nature, 443, 439443, doi:10.1038/nature05132, 2006.

Bousquet, P., Ringeval, B., Pison, I., Dlugokencky, E. J., Brunke, E.G., Carouge, C., Chevallier, F., Fortems-Cheiney, A., Frankenberg, C., Hauglustaine, D. A., Krummel, P. B., Langenfelds, R.
L., Ramonet, M., Schmidt, M., Steele, L. P., Szopa, S., Yver, C., Viovy, N., and Ciais, P.: Source attribution of the changes in atmospheric methane for 2006-2008, Atmos. Chem. Phys., 11, 3689-3700, doi:10.5194/acp-11-3689-2011, 2011.

Bregman, A., Krol, M. C., Teyssèdre, H., Norton, W. A., Iwi, A., Chipperfield, M., Pitari, G., Sundet, J. K., and Lelieveld, J.: Chemistry-transport model comparison with ozone observations in the midlatitude lowermost stratopshere, J. Geophys. Res., 106, 17479-17496, doi:10.1029/2000JD900752, 2001.

Brown, A. R., Cederwall, R. T., Chlond, A., Duynkerke, P. G., Golaz, J.-C., Khairoutdinov, M., Lewellen, D. C., Lock, A. P., Macvean, M. K., Moeng, C.-H., Neggers, R. A. J., Siebesma, A. P., and Stevens, B.: Large-eddy simulation of the diurnal cycle of shallow cumulus convection over land, Q. J. R. Meteorol. Soc., 128, 1075-1093, 2002.

Chambers, S. D., Zahorowski, W., Williams, A. G., Crawford, J., and Griffiths, A. D.: Identifying tropospheric baseline air masses at Mauna Loa Observatory between 2004 and 2010 using Radon222 and back trajectories, J. Geophys. Res.-Atmos., 118, 9921004, 2013.

Chen, B., Chen, J. M., and Liu, J.: A Vertical Diffusion Scheme to estimate the atmospheric rectifier effect, J. Geophys. Res., 109, D04306, doi:10.1029/2003JD003925, 2004.

Chen, Y.-H. and Prinn, R. G.: Estimation of atmospheric methane emissions between 1996 and 2001 using a three-dimensional global chemical transport model, J. Geophys. Res., 111, 1-25, doi:10.1029/2005JD006058, 2006.

Chevallier, F., Fisher, M., Peylin, P., Serrar, S., Bousquet, P., Bréon, F.-M., Chédin, A., and Ciais, P.: Inferring $\mathrm{CO}_{2}$ sources and sinks from satellite observations: Method and application to TOVS data, J. Geophys. Res., 110, 1-13, doi:10.1029/2005JD006390, 2005.

Chevallier, F., Feng, L., Bösch, H., Palmer, P. I., and Rayner, P. J.: On the impact of transport model errors for the estimation of $\mathrm{CO}_{2}$ surface fluxes from GOSAT observations, Geophys. Res. Lett., 37, L21803, doi:10.1029/2010GL044652, 2010.

Ciais, P., Sabine, C., Govindasamy, B., Bopp, L., Brovkin, V., Canadell, J., Chhabra, A., DeFries, R., Galloway, J., Heimann, M., Jones, C., Le Quéré, C., Myneni, R., Piao, S., and Thornton, P.: Chapter 6: Carbon and Other Biogeochemical Cycles, Climate Change 2013 The Physical Science Basis, edited by: Stocker, T., Qin, D., and Platner, G.-K., Cambridge University Press, Cambridge, 2013.

Couvreux, F., Hourdin, F., and Rio, C.: Resolved versus parametrized boundary-layer plumes. Part I: A parametrizationoriented conditional sampling in large-eddy simulations, Bound.Lay. Meteorol., 134, 441-458, doi:10.1007/s10546-009-9456-5, 2010.

Deardorff, J.: The counter-gradient heat flux in the lower atmosphere and in the laboratory, J. Atmos. Sci., 23, 503-506, 1966.

Denning, A. S., Fung, I. Y., and Randall, D. A.: Latitudinal gradient of atmospheric $\mathrm{CO}_{2}$ due to seasonal exchange with land biota, Nature, 376, 240-243, doi:10.1038/376240a0, 1995.

Denning, A. S., Holzer, M., Gurney, K. R., Heimann, M., Law, R. M., Rayner, P. J., Fung, I. Y., Fan, S.-M., Taguchi, S., Friedlingstein, P., Balkanski, Y., Taylor, J., Maiss, M., and Levin, I.: Three-dimensional transport and concentration of $\mathrm{SF}_{6}$. A model intercomparison study (TransCom 2), Tellus B, 51, 266297, doi:10.1034/j.1600-0889.1999.00012.x, 1999. 
Dlugokencky, E. J., Nisbet, E. G., Fisher, R., and Lowry, D.: Global atmospheric methane: budget, changes and dangers, Philos. Trans. Ser. A, 369, 2058-72, doi:10.1098/rsta.2010.0341, 2011.

Dufresne, J., Foujols, M., Denvil, S., and Caubel, A.: Climate change projections using the IPSL-CM5 Earth System Model: from CMIP3 to CMIP5, Clim. Dynam., 40, 2123-2165, doi:10.1007/s00382-012-1636-1, 2013.

Emanuel, K.: A Scheme for Representing Cumulus Convection in Large-Scale Models, J. Atmos. Sci., 48, 2313-2329, doi:10.1175/1520-0469(1991)048<2313:ASFRCC2.0.CO;2, 1991.

Galmarini, S.: Stable nocturnal boundary layers: a comparison of one-dimensional and large-eddy simulation models, Bound.-Lay. Meteorol., 88, 181-210, 1998.

Ganesan, A. L., Rigby, M., Zammit-Mangion, A., Manning, A. J., Prinn, R. G., Fraser, P. J., Harth, C. M., Kim, K.-R., Krummel, P. B., Li, S., Mühle, J., O’Doherty, S. J., Park, S., Salameh, P. K., Steele, L. P., and Weiss, R. F.: Characterization of uncertainties in atmospheric trace gas inversions using hierarchical Bayesian methods, Atmos. Chem. Phys., 14, 3855-3864, doi:10.5194/acp14-3855-2014, 2014.

Gaudry, A., Monfray, P., Polian, G., and Lambert, G.: Radoncalibrated emissions of $\mathrm{CO}_{2}$ from South Africa, Tellus B, 42B, 9-19, 1990.

Geels, C., Gloor, M., Ciais, P., Bousquet, P., Peylin, P., Vermeulen, A. T., Dargaville, R., Aalto, T., Brandt, J., Christensen, J. H., Frohn, L. M., Haszpra, L., Karstens, U., Rödenbeck, C., Ramonet, M., Carboni, G., and Santaguida, R.: Comparing atmospheric transport models for future regional inversions over Europe - Part 1: mapping the atmospheric $\mathrm{CO}_{2}$ signals, Atmos. Chem. Phys., 7, 3461-3479, doi:10.5194/acp-7-3461-2007, 2007.

Genthon, C. and Armengaud, A.: ${ }^{222}$ Radon as a comparative tracer of transport and mixing general in two circulation models of the atmosphere, J. Geophys. Res., 100, 2849-2866, 1995.

Grandpeix, J.-Y. and Lafore, J.-P.: A Density Current Parameterization Coupled with Emanuel's Convection Scheme, Part I: The Models, J. Atmos. Sci., 67, 881-897, 2010.

Griffiths, A. D., Zahorowski, W., Element, A., and Werczynski, S.: A map of radon flux at the Australian land surface, Atmos. Chem. Phys., 10, 8969-8982, doi:10.5194/acp-10-8969-2010, 2010.

Gurney, K. R., Law, R. M., Denning, A. S., Rayner, P. J., Baker, D., Bousquet, P., Bruhwilerk, L., Chen, Y.-H., Ciais, P., Fan, S., and Fung, I. Y.: Towards robust regional estimates of $\mathrm{CO}_{2}$ sources and sinks using atmospheric transport models, Nature, 415, doi:10.1038/415626a, 2002.

Gurney, K. R., Law, R. M., Denning, A. S., Rayner, P. J., Baker, D., Bousquet, P., Bruhwiler, L., Chen, Y.-H., Ciais, P., Fan, S., Fung, I. Y., Gloor, M., Heimann, M., Higuchi, K., John, J., Kowalczyk, E., Maki, T., Maksyutov, S., Peylin, P., Prather, M., Pak, B. C., Sarmiento, J., Taguchi, S., Takahashi, T. and Yuen, C.-W.: TransCom $3 \mathrm{CO}_{2}$ inversion intercomparison: 1 . Annual mean control results and sensitivity to transport and prior flux information, Tellus B, 55, 555-579, doi:10.1034/j.16000889.2003.00049.x, 2003.

Hatakka, J., Aalto, T., Aaltonen, V., Aurela, M., Hakola, H., Kompula, M., Laurila, T., Lihavainen, H., Paatero, J., Salminen, K., and Viisanen, Y.: Overview of the atmospheric research activi- ties and results at Pallas GAW station, Boreal Environ. Res., 8, 365-383, 2003.

Hauglustaine, D. A., Hourdin, F., Jourdain, L., Filiberti, M.A., Walters, S., Lamarque, J.-F., and Holland, E. A.: Interactive chemistry in the Laboratoire de Meterologie Dynamique general circulation model: Description and background tropospheric chemistry evaluation, J. Geophys. Res., 109, D04314, doi:10.1029/2003JD003957, 2004.

Hein, R., Crutzen, P. J., and Heimann, M.: An inverse modeling approach to investigate the global atmospheric methane cycle, Global Biogeochem. Cy., 11, 43-76, doi:10.1029/96GB03043, 1997.

Heinrich, P. and Jamelot, A.: Atmospheric transport simulation of $210 \mathrm{~Pb}$ and $7 \mathrm{Be}$ by the LMDz general circulation model and sensitivity to convection and scavenging parameterization, J. Atmos. Res., 101, 54-66, doi:10.1016/j.atmosres.2011.01.008, 2011

Holton, J., Haynes, P., and McIntyre, M.: Stratosphere Troposphere exchange, Rev. Geophysics, 33, 403-439, 1995.

Hourdin, F., Couvreux, F., and Menut, L.: Parameterization of the dry convective boundary layer based on a mass flux representation of thermals, J. Atmos. Sci., 59, 1105-1123, doi:10.1175/1520-0469(2002)059<1105:POTDCB>2.0.CO;2, 2002.

Hourdin, F., Musat, I., Bony, S., Braconnot, P., Codron, F., Dufresne, J.-L., Fairhead, L., Filiberti, M.-A., Friedlingstein, P., Grandpeix, J.-Y., Krinner, G., LeVan, P., Li, Z.-X., and Lott, F.: The LMDZ4 general circulation model: climate performance and sensitivity to parametrized physics with emphasis on tropical convection, Clim. Dynam., 27, 787-813, doi:10.1007/s00382006-0158-0, 2006.

Hourdin, F., Foujols, M.-A., Codron, F., Guemas, V., Dufresne, J.L., Bony, S., Denvil, S., Guez, L., Lott, F., Ghattas, J., Braconnot, P., Marti, O., Meurddesoif, Y. and Bopp, L.: Impact of the LMDZ atmospheric grid configuration on the climate and sensitivity of the IPSL-CM5A coupled model, Clim. Dynam., 40, 2193-2222, doi:10.1007/s00382-012-1411-3, $2013 \mathrm{a}$.

Hourdin, F., Grandpeix, J.-Y., Rio, C., Bony, S., Jam, A., Cheruy, F., Rochetin, N., Fairhead, L., Idelkadi, A., Musat, I., Dufresne, J. L., Lahellec, A., Lefebvre, M.-P. and Roehrig, R.: LMDZ5B: the atmospheric component of the IPSL climate model with revisited parameterizations for clouds and convection, Clim. Dynam., 40, 2193-2222, doi:10.1007/s00382-012-1343-y, 2013 b.

Houweling, S., Kaminski, T., Dentener, F., Lelieveld, J., and Heimann, M.: Inverse modeling of methane sources and sinks using the adjoint of a global transport model, J. Geophys. Res., 104, 26137, doi:10.1029/1999JD900428, 1999.

Houweling, S., Aben, I., Breon, F.-M., Chevallier, F., Deutscher, N., Engelen, R., Gerbig, C., Griffith, D., Hungershoefer, K., Macatangay, R., Marshall, J., Notholt, J., Peters, W., and Serrar, S.: The importance of transport model uncertainties for the estimation of $\mathrm{CO}_{2}$ sources and sinks using satellite measurements, Atmos. Chem. Phys., 10, 9981-9992, doi:10.5194/acp-10-99812010, 2010.

Houweling, S., Badawy, B., and Baker, D.: Iconic $\mathrm{CO}_{2}$ time series at risk, Science, 337, 1038-1040, doi:10.1126/science.337.6098.1038-b, 2012.

Houweling, S., Krol, M., Bergamaschi, P., Frankenberg, C., Dlugokencky, E. J., Morino, I., Notholt, J., Sherlock, V., Wunch, D., Beck, V., Gerbig, C., Chen, H., Kort, E. A., Röckmann, T., and 
Aben, I.: A multi-year methane inversion using SCIAMACHY, accounting for systematic errors using TCCON measurements, Atmos. Chem. Phys., 14, 3991-4012, doi:10.5194/acp-14-39912014, 2014.

Jacob, D., Prather, M., Rasch, P., and Shia, R.: Evaluation and intercomparison of global atmospheric transport models using ${ }^{222} R n$ and other short lived tracers, J. Geophys. Res., 102, 5953-5970, 1997.

Kai, F. M., Tyler, S. C., Randerson, J. T., and Blake, D. R.: Reduced methane growth rate explained by decreased Northern Hemisphere microbial sources, Nature, 476, 194-197, doi:10.1038/nature10259, 2011.

Karstens, U., Schwingshackl, C., Schmithüsen, D., and Levin, I.: A process-based ${ }^{222}$ Radon flux map for Europe and its validation by long-term observations, in preparation, 2014.

Kim, W.-H., Ko, H.-J., Hu, C.-G., Lee, H., Lee, C., Chambers, S., Williams, A. G., and Kang, C.-H.: Background Level of Atmospheric Radon-222 Concentrations at Gosan Station, Jeju Island, Korea in 2011, Bull. Korean Chem. Soc., 35, doi:10.5012/bkcs.2014.35.4.1149, 2014.

Kirschke, S., Bousquet, P., Ciais, P., Saunois, M., Bergamaschi, P., Bergmann, D., Bruhwiler, L., Cameron-Smith, P., Canadell, J. G., Castaldi, S., Chevallier, F., Dlugokencky, E. J., Feng, L., Fraser, A., Heimann, M., Hodson, E. L., Houweling, S., Josse, B., Lamarque, J.-F., Le Quére, C., Naik, V., Palmer, P. I., Pison, I., Plummer, D., Poulter, B., Ringeval, B., Santini, M., Schmidt, M., Shindell, D. T., Spahni, R., Strode, S. A., Sudo, K., Szopa, S., van der Werf, G. R., Voulgarakis, A., van Weele, M., Williams, J. E., and Zeng, G.: Three decades of methane sources and sinks: budgets and variations, Nat. Geosci., 6, 813823, doi:10.1038/ngeo1955, 2013.

Lafore, J. P., Stein, J., Asencio, N., Bougeault, P., Ducrocq, V., Duron, J., Fischer, C., Héreil, P., Mascart, P., Masson, V., Pinty, J. P., Redelsperger, J. L., Richard, E., and Vilà-Guerau de Arellano, J.: The Meso-NH Atmospheric Simulation System. Part I: adiabatic formulation and control simulations, Ann. Geophys., 16, 90-109, doi:10.1007/s00585-997-0090-6, 1998.

Laval, K., Sadourny, R., and Serafini, Y.: Land surface processes in a simplified general circulation model, Geophys. Astrophys. Fluid Dyn., 17, 129-150, 1981.

Law, R., Rayner, P., Denning, A. S., Erickson, D., Fung, I. Y., Heimann, M., Piper, S.C., Ramonet, M., Taguchi, S., Taylor, J. A., Trudinger, C. M., and Watterson, I. G.: Variations in modeled atmospheric transport of carbon dioxide and the consequences for $\mathrm{CO}_{2}$ inversions, Global Biogeochem. Cy., 10, 783796, doi:10.1029/96GB01892, 1996.

Law, R., Peters, W., Rödenbeck, C., Aulagnier, C., Baker, I., Bergmann, D., Bousquet, P., Brandt, J., Bruhwiler, L., CameronSmith, P., Christensen, J., Delage, F., Denning, A. S., Fan, S., Geels, C., Houweling, S., Imasu, R., Karstens, U., Kawa, S., Kleist, J., Krol, M., Lin, S.-J., Lokupitiya, R., Maki, T., Maksyutov, S., Niwa, Y., Onishi, R., Parazoo, N., Patra, P., Pieterse, G., Rivier, L., Satoh, M., Serrar, S., Taguchi, S., Takigawa, M., Vautard, R., Vermeulen, A. and Zhu, Z.: TransCom model simulations of hourly atmospheric $\mathrm{CO}_{2}$ : Experimental overview and diurnal cycle results for 2002, Global Biogeochem. Cy., 22, GB3009, doi:10.1029/2007GB003050, 2008.
Lelieveld, J. and Crutzen, P. J.: Role of Deep Cloud Convection in the Ozone Budget of the Troposphere, Science, 264, 1759-1761, 1994.

Levin, I., Born, M., Cuntz, M., Langendörfer, U., Mantsch, S., Naegler, T., Schmidt, M., Varlagin, A., Verclas, S., and Wagenbach, D.: Observations of atmospheric variability and soil exhaltation rate of radon-222 at a Russian forest site, Nature, 486, E3-4; discussion E4, doi:10.1038/nature11175, 2002.

Levin, I., Naegler, T., Heinz, R., Osusko, D., Cuevas, E., Engel, A., Ilmberger, J., Langenfelds, R. L., Neininger, B., Rohden, C. v., Steele, L. P., Weller, R., Worthy, D. E., and Zimov, S. A.: The global SF6 source inferred from long-term high precision atmospheric measurements and its comparison with emission inventories, Atmos. Chem. Phys., 10, 2655-2662, doi:10.5194/acp-102655-2010, 2010.

Levin, I., Veidt, C., Vaughn, B. H., Brailsford, G., Bromley, T., Heinz, R., Lowe, D., Miller, J. B., Poß, C., and White, J. W. C.: No inter-hemispheric $\delta 13 \mathrm{CH}_{4}$ trend observed, Nature, 486, E34; discussion E4, doi:10.1038/nature11175, 2012.

Li, Z.: Ensemble atmospheric GCM simulation of climate interannual variability from 1979 to 1994, J. Climate, 12, 986-1001, 1999.

Li, Z. and Conil, S.: A 1000-year simulation with the IPSL oceanatmosphere coupled model, Ann. Geophys., 46, doi:10.4401/ag3387, 2003.

Locatelli, R., Bousquet, P., Chevallier, F., Fortems-Cheney, A., Szopa, S., Saunois, M., Agusti-Panareda, A., Bergmann, D., Bian, H., Cameron-Smith, P., Chipperfield, M. P., Gloor, E., Houweling, S., Kawa, S. R., Krol, M., Patra, P. K., Prinn, R. G., Rigby, M., Saito, R., and Wilson, C.: Impact of transport model errors on the global and regional methane emissions estimated by inverse modelling, Atmos. Chem. Phys., 13, 99179937, doi:10.5194/acp-13-9917-2013, 2013.

Lopez, M., Schmidt, M., Yver, C., Messager, C., Worthy, D., Kazan, V., Ramonet, M., Bousquet, P., and Ciais, P.: Seasonal variation of $\mathrm{N}_{2} \mathrm{O}$ emissions in France inferred from atmospheric $\mathrm{N}_{2} \mathrm{O}$ and ${ }^{222} \mathrm{Rn}$ measurements, J. Geophys. Res., 117, D14103, doi:10.1029/2012jd017703, 2012.

Louis, J.: A parametric model of vertical eddy fluxes in the atmosphere, Bound.-Lay. Meteorol., 7, 187-202, doi:10.1007/BF00117978, 1979.

Lowry, D., Holmes, C. W., and Rata, N. D.: London methane emissions: Use of diurnal changes in concentration and $\delta^{13} C$ to identify urban sources and verify inventories, J. Geophys. Res., 106, 7427-7448, doi:10.1029/2000JD900601, 2001.

Maiss, M. and Brenninkmeijer, C.: Atmospheric $\mathrm{SF}_{6}$ : trends, sources, and prospects, Environ. Sci., 32, 3077-3086, 1998.

Maiss, M., Steele, L., and Francey, R.: Sulfur hexafluoride: A powerful new atmospheric tracer, Atmos. Environ., 30, 1621-1629, 1996.

Mahowald, N. M., Rasch, P. J., and Prinn, R. G.: Cumulus parameterizations in chemical transport models, J. Geophys. Res., 100, 26173-26189, doi:10.1029/95JD02606, 1995.

Mahowald, N. M., Rasch, P. J., Eaton, B. E., Whittleston, S., and Prinn, R. G.: Transport of ${ }^{222}$ Radon to the remote troposphere using MATCH and assimilated winds from ECMWF and NCEP/NCAR, J. Geophys. Res., 102, 28139-28152, 1997. 
Marti, O., Braconnot, P., and Dufresne, J.: Key features of the IPSL ocean atmosphere model and its sensitivity to atmospheric resolution, Clim. Dynam., 34, 1-26, 2010.

McGrath-Spangler, E. L. and Denning, A. S.: Global seasonal variations of midday planetary boundary layer depth from CALIPSO space-borne LIDAR, J. Geophys. Res., 118, 12261233, doi:10.1002/jgrd.50198, 2013.

Monteil, G., Houweling, S., Butz, A., Guerlet, S., Schepers, D., Hasekamp, O., Frankenberg, C., Scheepmaker, R., Aben, I. and Röckmann, T.: Comparison of $\mathrm{CH}_{4}$ inversions based on 15 months of GOSAT and SCIAMACHY observations, J. Geophys. Res., 118, 11807-11823, doi:10.1002/2013JD019760, 2013.

Montzka, S. A., Dlugokencky, E. J., and Butler, J. H.: Non$\mathrm{CO}_{2}$ greenhouse gases and climate change, Nature, 476, 43-50, doi:10.1038/nature10322, 2011.

Morris, R. A., Miller, T. M., Viggiano, A. A., Paulson, J. F., Solomon, S., and Reid, G.: Effects of electron and ions reactions on atmospheric lifetimes of fully fluorinated compounds, J. Geophys. Res., 100, 1287-1294, doi:10.1029/94JD02399, 1997.

Naik, V., Voulgarakis, A., Fiore, A. M., Horowitz, L. W., Lamarque, J.-F., Lin, M., Prather, M. J., Young, P. J., Bergmann, D., Cameron-Smith, P. J., Cionni, I., Collins, W. J., Dalsøren, S. B., Doherty, R., Eyring, V., Faluvegi, G., Folberth, G. A., Josse, B., Lee, Y. H., MacKenzie, I. A., Nagashima, T., van Noije, T. P. C., Plummer, D. A., Righi, M., Rumbold, S. T., Skeie, R., Shindell, D. T., Stevenson, D. S., Strode, S., Sudo, K., Szopa, S., and Zeng, G.: Preindustrial to present-day changes in tropospheric hydroxyl radical and methane lifetime from the Atmospheric Chemistry and Climate Model Intercomparison Project (ACCMIP), Atmos. Chem. Phys., 13, 5277-5298, doi:10.5194/acp-13-5277-2013, 2013.

Patra, P. K., Takigawa, M., Ishijima, K., Choi, B.-C., Cunnold, D., Dlugokencky, E. J., Fraser, P.,Gomez-Pelaez, A. J., Goo, T.-Y., Kim, J.-S., Krummel, P., Langenfelds, R., Meinhardt, F., Mukai, H., O'Doherty, S., Prinn, R. G., Simmonds, P., Steele, P., Tohjima, Y., Tsuboi, K., Uhse, K., Weiss, R., Worthy, D., and Nakazawa, T.: Growth Rate, Seasonal, Synoptic, Diurnal Variations and Budget of Methane in the Lower Atmosphere, J. Met. Soc. Jpn., 87, 635-663, doi:10.2151/jmsj.87.635, 2009.

Patra, P. K., Houweling, S., Krol, M., Bousquet, P., Belikov, D., Bergmann, D., Bian, H., Cameron-Smith, P., Chipperfield, M. P., Corbin, K., Fortems-Cheiney, A., Fraser, A., Gloor, E., Hess, P., Ito, A., Kawa, S. R., Law, R. M., Loh, Z., Maksyutov, S., Meng, L., Palmer, P. I., Prinn, R. G., Rigby, M., Saito, R., and Wilson, C.: TransCom model simulations of $\mathrm{CH} 4$ and related species: linking transport, surface flux and chemical loss with $\mathrm{CH} 4$ variability in the troposphere and lower stratosphere, Atmos. Chem. Phys., 11, 12813-12837, doi:10.5194/acp-11-12813-2011, 2011.

Peylin, P., Rayner, P. J., Bousquet, P., Carouge, C., Hourdin, F., Heinrich, P., Ciais, P., and AEROCARB contributors: Daily $\mathrm{CO}_{2}$ flux estimates over Europe from continuous atmospheric measurements: 1, inverse methodology, Atmos. Chem. Phys., 5, 3173-3186, doi:10.5194/acp-5-3173-2005, 2005.

Pison, I., Bousquet, P., Chevallier, F., Szopa, S., and Hauglustaine, D.: Multi-species inversion of $\mathrm{CH}_{4}, \mathrm{CO}$ and $\mathrm{H}_{2}$ emissions from surface measurements, Atmos. Chem. Phys., 9, 5281-5297, doi:10.5194/acp-9-5281-2009, 2009.

Popa, M. E., Vermeulen, A. T., van den Bulk, W. C. M., Jongejan, P. A. C., Batenburg, A. M., Zahorowski, W., and Röckmann, T.: $\mathrm{H}_{2}$ vertical profiles in the continental boundary layer: measurements at the Cabauw tall tower in The Netherlands, Atmos. Chem. Phys., 11, 6425-6443, doi:10.5194/acp-11-6425-2011, 2011.

Prinn, R. G., Huang, J., Weiss, R. F., Cunnold, D. M., Fraser, P. J., Simmonds, P. G., McCulloch, A., Harth, C., Reimann, S., Salameh, P., O’Doherty, S., Wang, R. H. J., Porter, L. W., Miller, B. R., and Krummerl, P. B.: Evidence for variability of atmospheric hydroxyl radicals over the past quarter century, Geophys. Res. Lett., 32, L07809, doi:10.1029/2004GL022228, 2005.

Randerson, J. T., Thompson, M. V., Conway, T. J., Fung, I. Y., and Field, C. B.: The contribution of terrestrial sources and sinks to trends in the seasonal cycle of atmospheric carbon dioxide, Global Biogeochem. Cy., 11, 535-560, 1997.

Ravishankara, A. R., Solomon, S., Turnipseed, A. A., and Warren, R. F.: Atmospheric lifetimes of long-lived halogenated species, Science, 259, 194-199, 1993.

Rayner, P., Enting, I., Francey, R., and Langenfelds, R.: Reconstructing the recent carbon cycle from atmospheric $\mathrm{CO} 2, \delta 13 \mathrm{C}$ and $\mathrm{O}_{2} / \mathrm{N}_{2}$ observations, Tellus $\mathrm{B}, 51,213-232,1999$.

Reichler, T., Dameris, M., and Sausen, R.: Determining the tropopause height from gridded data, Geophys. Res. Lett., 30, 2042, doi:10.1029/2003GL018240, 2003.

Rigby, M., Prinn, R. G., Fraser, P. J., Simmonds, P. G., Langenfelds, R. L., Huang, J., Cunnold, D. M., Steele, L. P., Krummel, P. B., Weiss, R. F., O’Doherty, S., Salameh, P. K., Wang, H. J., Harth, C. M., Mühle, J., and Porter, L. W.: Renewed growth of atmospheric methane, Geophys. Res. Lett., 35, 213 232, doi:10.1029/2008GL036037, 2008.

Rio, C. and Hourdin, F.: A thermal plume model for the convective boundary layer: representation of cumulus clouds, J. Atmos. Sci., 65, 407-425, doi:10.1175/2007JAS2256.1, 2008.

Rio, C., Hourdin, F., Grandpeix, J.-Y., and Lafore, J.-P.: Shifting the diurnal cycle of parameterized deep convection over land, Geophys. Res. Lett., 36, L07809, doi:10.1029/2008GL036779, 2009.

Rodgers, C. D.: Inverse Methods for Atmospheric Sounding: Theory and Ptractice, World Scientific Publishing Co. Ltd, London, United-Kingdom, 2000.

Saito, R., Patra P., Sweeney, C., Machida, T., Krol, M., Houweling, S., Bousquet, P., Agusti-panareda, A., Belikov, D., Bergmann, D., Bian, H., Cameron-Smith, P., Chipperfield, M., FortemsCheney, A., Fraser, A., Gatti, M., Gloor, E., Hess, P., Kawa, S., Law, R., Locatelli, R., Loe, Z., Maksyutov, S., Meng, L., Miller, J., Palmer, P., Prinn, R., Rigby, M. and Wilson, C.: TransCom model simulations of methane: comparison of vertical profiles with in situ aircraft measurements, J. Geophys. Res., 35, L22805, doi:10.1029/2008GL036037, 2013.

Scheeren, H. A. and Bergamaschi, P.: First Three Years of $\mathrm{CO}_{2}$, $\mathrm{CH}_{4}, \mathrm{~N}_{2} \mathrm{O}$, and $\mathrm{SF}_{6}$ Observations, and ${ }^{222}$ Radon-Based Emission Estimates from the JRC Monitoring Station at Ispra (Italy): What Have We Learned So Far?, proceeding of the 16th WMO/IAEA Meeting on Carbon Dioxide, Other Greenhouse Gases and Related Measurement Techniques (GGMT-2011), Wellington, New Zealand, World Meteorological Organization, 2012.

Schmithüsen, D.: Assessment of the Heidelberg static filter ${ }^{222}$ Radon monitor and its comparison to various measurement systems at European observatories, in preparation, 2015. 
Segers, A., Velthoven, P., Bregman, B., and Krol, M.: On the computation of Mass Fluxes for Eulerian Transport Models from Spectral Meteorological Fields, Computational Science - ICCS 2002, 2330, 767-776, doi:10.1007/3-540-46080-2, 2002.

Seidel, D. J., Zhang, Y., Beljaars, A. C. M., Golaz, J.-C., Jacobson, A. R., and Medeiros, B.: Climatology of the planetary boundary layer over the continental United States and Europe, J. Geophys. Res., 117, D17106, doi:10.1029/2012JD018143, 2012.

Slemr, F., Brunke, E.-G., Whittlestone, S., Zahorowski, W., Ebinghaus, R., Kock, H. H., and Labuschagne, C.: ${ }^{222}$ Rn-calibrated mercury fluxes from terrestrial surface of southern Africa, Atmos. Chem. Phys., 13, 6421-6428, doi:10.5194/acp-13-64212013, 2013.

Smallman, T. L., Williams, M., and Moncrieff, J. B.: Can seasonal and interannual variation in landscape $\mathrm{CO}_{2}$ fluxes be detected by atmospheric observations of $\mathrm{CO}_{2}$ concentrations made at a tall tower?, Biogeosciences, 11, 735-747, doi:10.5194/bg-11-7352014, 2014.

Stephens, B. B., Gurney, K. R., Tans, P. P., Sweeney, C., Peters, W., Bruhwiler, L., Ciais, P., Ramonet, M., Bousquet, P., Nakazawa, T., Aoki, S., Machida, T., Inoue, G., Vinnichenko, N., Lloyd, J., Jordan, A., Heimann, M., Shibistova, O., Langenfelds, R. L., Steele, L. P., Francey, R. J. and Denning, A. S.: Weak northern and strong tropical land carbon uptake from vertical profiles of atmospheric $\mathrm{CO}_{2}$, Science, 316, 1732-1735, 2007.

Stephens, B. B., Wofsy, S. C., Keeling, R. F., Tans, P. P., and Potosnak, M. J.: The $\mathrm{CO}_{2}$ Budget and Rectification Airborne Study: Strategies for Measuring Rectifiers and Regional Fluxes, in: Inverse Methods in Global Biogeochemical Cycles, edited by: Kasibhatla, P., Heimann, M., Rayner, P., Mahowald, N., Prinn, R. G., and Hartley, D. E, American Geophysical Union, Washington D.C., doi:10.1029/GM114p0311, 2013.

Tarantola, A.: Inverse Problem Theory, Society for Industrial and Applied Mathematics, Philadelphia, USA, 2005.

Thompson, R. L., Patra, P. K., Ishijima, K., Saikawa, E., Corazza, M., Karstens, U., Wilson, C., Bergamaschi, P., Dlugokencky, E., Sweeney, C., Prinn, R. G., Weiss, R. F., O’Doherty, S., Fraser, P. J., Steele, L. P., Krummel, P. B., Saunois, M., Chipperfield, M., and Bousquet, P.: TransCom N2O model inter-comparison - Part 1: Assessing the influence of transport and surface fluxes on tropospheric $\mathrm{N}_{2} \mathrm{O}$ variability, Atmos. Chem. Phys., 14, 43494368, doi:10.5194/acp-14-4349-2014, 2014.

Tiedtke, M.: A comprehensive mass flux scheme for cumulus parameterization in large-scale models, Mon. Weather Rev., 117, 1779-1800, doi:10.1175/15200493(1989)117<1779:ACMFSF>2.0.CO;2, 1989.

Tost, H., Lawrence, M. G., Brühl, C., and Jöckel, P.: The GABRIEL Team, and The SCOUT-O3-DARWIN/ACTIVE Team: Uncertainties in atmospheric chemistry modelling due to convection parameterisations and subsequent scavenging, Atmos. Chem. Phys., 10, 1931-1951, doi:10.5194/acp-10-1931-2010, 2010.

van der Laan, S., Karstens, U., Neubert, R. E. M., van der LaanLuijkx, I. T., and Meijer, H. A. J.: Observation-based estimates of fossil fuel-derived $\mathrm{CO}_{2}$ emissions in the Netherlands using Delta $14^{C}$, CO and ${ }^{222}$ Radon, Tellus B, 62, 389-402, doi:10.1111/j.1600-0889.2010.00493.x, 2010.
Vermeulen, A. T., Hensen, A., Popa, M. E., van den Bulk, W. C. M., and Jongejan, P. A. C.: Greenhouse gas observations from Cabauw Tall Tower (1992-2010), Atmos. Meas. Tech., 4, 617644, doi:10.5194/amt-4-617-2011, 2011.

Williams, A. G., Chambers, S., Zahorowski, W., Crawford, J., Matsumoto, K., and Uematsu, M.: Estimating the Asian radon flux density and its latitudinal gradient in winter using ground-based radon observations at Sado Island, Tellus B, 61, 732-746, 2009.

Williams, A. G., Zahorowski, W., Chambers, S., Griffiths, A., Hacker, J. M., Element, A., and Werczynski, S.: The Vertical Distribution of Radon in Clear and Cloudy Daytime Terrestrial Boundary Layers, J. Atmos. Sci., 68, 155-174, 2010.

Xia, Y., Sartorius, H., Schlosser, C., Stöhlker, U., Conen, F., and Zahorowski, W.: Comparison of one- and two-filter detectors for atmospheric ${ }^{222} \mathrm{Rn}$ measurements under various meteorological conditions, Atmos. Meas. Tech., 3, 723-731, doi:10.5194/amt-3723-2010, 2010.

Yamada, T.: Simulations of nocturnal drainage flows by a q21 turbulence closure model, J. Atmos. Sci., 40, 91-106, 1983.

Yi, C., Davis K. J., Bakwin, P. S., Denning, A. S., Zhang, N., Desai, A., Lin, J. C., and Gerbig, C.: Observed covariance between ecosystem carbon exchange and atmospheric boundary layer dynamics at a site in northern Wisconsin, J. Geophys. Res., 109, D08302, doi:10.1029/2003JD004164, 2004.

Yver, C., Schmidt, M., Bousquet, P., Zahorowski, W., and Ramonet, M.: Estimation of the molecular hydrogen soil uptake and traffic emissions at a suburban site near Paris through hydrogen, carbon monoxide, and radon-222 semicontinuous measurements, J. Geophys. Res., 114, D18304, doi:10.1029/2009jd012122, 2009.

Zahorowski, W., Griffiths, A., and Chambers, S.: Constraining annual and seasonal radon-222 flux density from the Southern Ocean using radon-222 concentrations in the boundary layer at Cape Grim, Tellus B, 1, 1-18, 2013.

Zhang, M. H., Lin, W. Y., Klein, S. A., Bacmeister, J. T., Bony, S., Cederwall, R. T., Del Genio, A. D., Hack, J. J., Loeb, N. G., Lohmann, U., Minnis, P., Musat, I., Pincus, R., Stier, P., Suarez, M. J., Webb, M. J., Wu, J. B., Xie, S. C., Yao, M.-S., and Zhang, J. H.: Comparing clouds and their seasonal variations in 10 atmospheric general circulation models with satellite measurements, J. Geophys. Res., 110, D15S02, doi:10.1029/2004JD005021, 2005.

Zhang, K., Feichter, J., Kazil, J., Wan, H., Zhuo, W., Griffiths, A. D., Sartorius, H., Zahorowski, W., Ramonet, M., Schmidt, M., Yver, C., Neubert, R. E. M., and Brunke, E.-G.: Radon activity in the lower troposphere and its impact on ionization rate: a global estimate using different radon emissions, Atmos. Chem. Phys., 11, 7817-7838, doi:10.5194/acp-11-7817-2011, 2011. 